\title{
Receptory błonowe wiążące cząsteczki typu MAMP/PAMP i DAMP aktywujące pierwszą linię obrony lokalnej układu odpornościowego roślin
}

\begin{abstract}
STRESZCZENIE
$\mathbf{R}_{\mathrm{d}}^{\mathrm{s}}$ ośliny w toku ewolucji wykształciły wielopoziomowy układ odpornościowy przeciwdziałający infekcjom oraz zapobiegający rozwojowi chorób. Pierwszą linię obrony aktywują receptory błonowe, określane jako receptory rozpoznające wzorce molekularne obcych cząsteczek (PRR), wiążące cząsteczki typu MAMP/PAMP lub DAMP. Receptory typu PRR aktywują kaskady sygnałowe uruchamiające odpowiedzi obronne tworzące odporność aktywowaną przez cząsteczki PAMP (PTI). Odpowiedzi obronne współtworzące pierwszą linię obrony obejmują $\mathrm{m}$. in. produkcję aktywnych form tlenu i tlenku azotu, odkładanie kalozy, zamykanie aparatów szparkowych, biosyntezę fitoaleksyn, biosyntezę fitohormonów związanych $\mathrm{z}$ odpornością oraz aktywację szerokiego zestawu genów związanych $\mathrm{z}$ reakcjami odpornościowymi.
\end{abstract}

\section{WPROWADZENIE}

Rośliny mogą żyć w środowisku razem z licznymi organizmami patogennymi dzięki wykształconym $w$ toku ewolucji mechanizmom odpornościowym przeciwdziałającym infekcjom przez fitopatogeny i zapobiegającym rozwojowi chorób. Oprócz bariery fizycznej (epiderma pokryta kutykułą, wielowarstwowa ściana komórkowa) i chemicznej (np. produkowane konstytutywnie fitoancypiny), pierwszą linię obrony stanowi odporność aktywowana przez receptory błonowe wiążące cząsteczki (elicytory) pochodzące z obcych drobnoustrojów. Cząsteczki te są nazywane ogólnie cząsteczkami typu MAMP (ang. Microbe-Associated Molecular Pattern), a gdy pochodzą z organizmów patogennych, cząsteczkami typu PAMP (ang. Pathogen-Associated Molecular Pattern). W aktywowaniu odporności podstawowej, u zwierząt nazywanej odpornością wrodzoną, mogą także brać udział cząsteczki pochodzące $\mathrm{z}$ komórek atakowanej rośliny, uwalniane $\mathrm{w}$ następstwie ataku fitopatogena lub produkowane $\mathrm{w}$ warunkach stresu. $\mathrm{W}$ tym wypadku cząsteczki noszą nazwę cząsteczek typu DAMP (ang. Damage/Danger-Associated Molecular Pattern) [1-3]. W percepcji cząsteczek MAMP/PAMP i DAMP pośredniczą zlokalizowane $\mathrm{w}$ błonie plazmatycznej białka receptorowe nazywane ogólnie receptorami typu PRR (ang. Pattern Recognition Receptor) [4-6]. Receptory PRR rozpoznają określony wzorzec molekularny (sygnaturę) obcej bądź własnej cząsteczki, identyfikując w ten sposób całe grupy organizmów patogennych i niepatogennych. Wiązanie cząsteczki MAMP/PAMP lub DAMP do receptora błonowego aktywuje wewnątrzkomórkowe szlaki sygnałowe uruchamiające $\mathrm{w}$ roślinie szeroki wachlarz odpowiedzi obronnych współtworzących odporność lokalną typu PTI (ang. PAMP-Triggered Immunity) $[6,7]$. Tak więc, w strategii obronnej roślin, odporność aktywowana przez cząsteczki MAMP/PAMP i DAMP stanowi pierwszą linię obrony lokalnej, dzięki której roślina nie tylko może przeciwdziałać infekcjom, ale może także aktywnie zwalczać pojawiające się organizmy patogenne. W wielu wypadkach, uruchamiane odpowiedzi obronne typu PTI są wystarczająco efektywne, by skutecznie chronić roślinę przed infekcją i namnażaniem się patogena, szczególnie zaś wtedy, gdy atakujący patogen nie dysponuje odpowiednimi mechanizmami supresyjnymi przełamującymi odporność PTI. Jednakże większość organizmów patogennych wykształciła w toku ewolucji szereg mechanizmów molekularnych nakierowanych na tłumienie odporności PTI. Kluczowy mechanizm supresyjny, wykorzystywany przez fitopatogeny $\mathrm{z}$ różnych grup systematycznych, opiera się na produkowanych przez fitopatogeny specjalnych białkach, nazywanych ogólnie efektorami, które wprowadzone do komórek atakowanej rośliny zaburzają odporność PTI. Niektóre poznane białka efektorowe blokują receptory PRR, inne atakują białka pośredniczące $w$ przekazywaniu sygnałów, a jeszcze inne zaburzają odpowiedzi obronne bądź naruszają różne procesy biochemiczne [8,9]. Jednakże $\mathrm{w}$ toku ewolucji, białka efektorowe syntetyzowane przez fitopatogeny stały się

\section{Anna Hetmann}

\section{Stanisław Kowalczyk}

Zakład Biochemii, Wydział Biologii i Ochrony Środowiska, Uniwersytet Mikołaja Kopernika w Toruniu

Zakład Biochemii, Wydział Biologii i Ochrony Środowiska, Uniwersytet Mikołaja Kopernika, ul. Lwowska 1, 87-100 Toruń; tel.: (56) 61126 95, e-mail: ahetmann@umk.pl

Artykuł otrzymano 15 grudnia 2017 r. Artykuł zaakceptowano 27 kwietnia 2018 r.

Słowa kluczowe: odporność podstawowa roślin, receptory rozpoznające cząsteczki MAMP/PAMP i DAMP, odpowiedzi obronne

Wykaz skrótów: DAMP (ang. Damage/Danger-Associated Molecular Pattern) - cząsteczka o określonym wzorcu molekularnym pochodząca z atakowanej rośliny; ETI (ang. Effector-Triggered Immunity) - odporność aktywowana przez efektor; MAMP (ang. Microbe-Associated Molecular Pattern) - cząsteczka (wzorzec molekularny) pochodząca z drobnoustrojów; PAMP (ang. Pathogen-Associated Molecular Pattern) - cząsteczka pochodząca $\mathrm{z}$ organizmu patogennego; PRR (ang. Pattern Recognition Receptor) - receptor rozpoznający określony wzorzec molekularny obcej bądź własnej cząsteczki; PTI (ang. PAMP-Triggered Immunity) - odporność aktywowana przez cząsteczkę PAMP; SAR (ang. Systemic Aquired Resistance) - odporność nabyta systemowo 
zarazem istotnymi elementami układu odpornościowego, dzięki którym w roślinie następuje aktywacja drugiej linii obrony lokalnej. Stało się to możliwe dzięki wykształconym w toku ewolucji wewnątrzkomórkowym immunoreceptorom rozpoznającym pojawiające się w komórkach roślin białka efektorowe fitopatogenów. Receptory te są tożsame z produktami genów $R$ (ang. Resistance), które w koncepcji Flora sprzed ponad 60 lat miały oddziaływać z produktami genów awirulentnych fitopatogenów. Największą i obecnie najlepiej poznaną grupę immunoreceptorów wewnątrzkomórkowych tworzą białka z rodziny NB-LRR (ang. Nucleotide-Binding site, Leucine-rich Repeat). Rozpoznają one białka efektorowe na zasadzie bezpośrednich oddziaływań typu ligand-receptor, chociaż znacznie częściej obecność efektora wykrywają pośrednio, monitorując zmiany we własnych białkach (kofaktorach), jakie pojawiają się w związku z obecnością białek efektorowych. Zmiany konformacyjne w białkach NB-LRR, towarzyszące rozpoznaniu białek efektorowych, aktywują szlaki sygnałowe uruchamiające odpowiedzi obronne typu ETI (ang. Effector-Triggered Immunity) [10]. Reakcje odpornościowe typu ETI są na ogół silniejsze niż PTI i zwykle obejmują reakcje typu nadwrażliwości HR (ang. Hypersensitive Response) prowadzące do programowanej śmierci komórek. Śmierć zainfekowanych komórek ma przeciwdziałać rozprzestrzenianiu się fitopatogena na sąsiednie, niezainfekowane jeszcze komórki.

W miejscu infekcji produkowane są cząsteczki sygnałowe, które w tkankach niezainfekowanych, również w tych położonych daleko od miejsca infekcji, indukują odporność nabytą systemowo SAR (ang. Systemic Aquired Resistance) [11]. Innym typem tzw. odporności indukowanej IR (ang. Induced Response) jest odporność ISR (ang. Induced Systemic Resistance) występująca w związku z oddziaływaniami pomiędzy rośliną a bakteriami i grzybami symbiotycznymi [12]. Przeprogramowanie ekspresji genów związane z odpornością typu PTI i ETI pociąga również szereg modyfikacji epigenetycznych, które stają się podstawą odporności indukowanej międzypokoleniowo (ang. Transgenerationally Induced Resistance) [13]. Fenomenem odporności indukowanej jest stan „uwrażliwienia” (ang. priming) układu odpornościowego rośliny charakteryzującego się wyraźnymi zmianami metabolicznymi, hormonalnymi, zmianami w aktywności enzymów oraz zmianami epigenetycznymi. Zjawisko „primingu” może być wywoływane przez śladowe ilości lub "słabe” cząsteczki typu MAMP/PAMP oraz przez wiele różnorodnych czynników stresogennych, takich jak np. zranienia, a także przez szereg różnych związków chemicznych, takich jak np.: kwas $\beta$-aminomasłowy, salicylan, jasmonian, czy lotne związki organiczne (VOCs, ang. Volatile Organic Compounds). Stan „uwrażliwienia” układu odpornościowego sprzyja szybszej i efektywniejszej obronie w sytuacji, gdy rzeczywiście nastąpi atak patogena [14,15].

Celem obecnej pracy było podsumowanie wyników dotychczasowych badań poświęconych identyfikowaniu cząsteczek typu MAMP/PAMP i DAMP oraz poznawaniu receptorów błonowych roślin typu PRR aktywujących wewnątrzkomórkowe szlaki przekazywania sygnałów uruchamiających odpowiedzi obronne typu PTI.

\section{RECEPTORY WIĄŻĄCE CZĄSTECZKI TYPU MAMP/ PAMP BAKTERII, GRZYBÓW I LĘGNIOWCÓW ORAZ WŁASNE CZĄSTECZKI TYPU DAMP}

W latach osiemdziesiątych ubiegłego wieku w doświadczeniach prowadzonych na kulturach komórkowych podejmowano szereg różnorodnych analiz tzw. szybkich odpowiedzi, jakie pojawiają się w związku z aplikacją obcych cząsteczek pochodzących z komórek bakterii, grzybów, lęgniowców czy nicieni. Wyniki tych doświadczeń pokazały, że identyfikowane elicytory wywołują nie tylko łatwo zauważalne zmiany morfologiczne i fizjologiczne, ale aktywują również zmiany w ekspresji genów związanych z odpornością roślin na patogeny [16]. Równolegle z poznawaniem różnorodnych elicytorów podejmowano także próby identyfikowania białek receptorowych pośredniczących $\mathrm{w}$ percepcji niektórych cząsteczek. Wyraźny przełom w tych poszukiwaniach nastąpił w 2000 roku po tym, jak w rzodkiewniku pospolitym (Arabidopis thaliana) zidentyfikowano gen AtFLS2 kodujący białko wiążące flagelinę, białko budujące wić bakterii [17]. W tym miejscu warto przypomnieć, że cztery lata wcześniej odkryto receptor błonowy Toll funkcjonujący w układzie odpornościowym wywilżni karłowatej (Drosophila melanogaster), a w 1998 roku u myszy zidentyfikowano gen TLR4 (ang. Toll-Like Receptor4) kodujący błonowe białko receptorowe pośredniczące $\mathrm{w}$ percepcji lipopolisacharydu (LPS), bakteryjnej cząsteczki typu MAMP/DAMP. Wyniki tych poszukiwań ukierunkowały w następnych latach badania molekularne poświęcone odporności wrodzonej u zwierząt, których doniosłość doceniono w 2011 roku przyznaniem J. A. Hoffmannowi i B. A. Beutlerowi nagrody Nobla w dziedzinie fizjologii i medycyny.

Odkrycie w rzodkiewniku receptora AtFLS2 zapoczątkowało lawinę badań poświęconych poznawaniu w roślinach receptorów błonowych wiążących cząsteczki MAMP/ PAMP i DAMP, aktywujących reakcje odpornościowe typu PTI. Wyniki tych badań wykazały, że odkrywane u roślin receptory wiążące cząsteczki MAMP/PAMP/DAMP łączy z białkami Toll/TLR zwierząt wiele podobieństw. Okazało się, że wszystkie białka Toll/TLR oraz duża część poznanych dotychczas białek receptorowych PRR roślin w części zewnątrzkomórkowej wiążącej ligand zawiera domenę utworzoną z wielu charakterystycznych 20-30-aminokwasowych powtórzeń bogatych w leucynę LRR (ang. Leucine Rich Repeats) [18]. Białka Toll/TLR za domeną zewnątrzkomórkową mają pojedynczą helisę transbłonową, za którą występuje wewnątrzkomórkowa domena TIR oddziałująca $\mathrm{z}$ białkami adaptorowymi pośredniczącymi w wiązaniu cytoplazmatycznych kinaz białkowych Pelle/IRAK, które są kluczowymi elementami wewnątrzkomórkowych szlaków sygnałowych [18]. W roślinach, błonowymi białkami receptorowymi PRR są receptorowe kinazy białkowe typu RLK (ang. Receptor-Like Kinase) bądź białka błonowe typu RLP (ang. Receptor-Like Proteins), które razem z kinazami białkowymi współtworzą kompleksy receptorowe. W tym miejscu warto zauważyć, że genom rzodkiewnika zawiera 443, genom ryżu 786, a genom brzozy (Populus trichocarpa) 726 sekwencji kodujących błonowe, receptorowe serynowo/treoninowe kinazy białkowe typu RLK/Pelle [19]. Rodzinę białek typu RLP w rzodkiewniku koduje 170, a w 


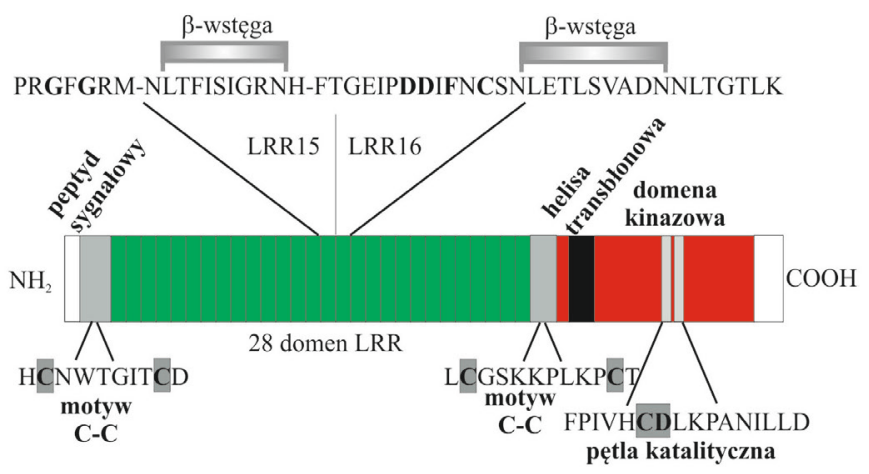

Rycina 1. Schemat polipeptydu AtFLS2. Opis w tekście (na podstawie prac [3,17], zmieniono).

ryżu 90 genów [20]. W ponad 230 kinazach RLK rzodkiewnika, domenę zewnątrzkomórkową wiążącą ligand tworzy kilka, do kilkudziesięciu powtórzeń typu LRR. W pozostałych kinazach RLK w tym miejscu występują domeny lektynowe, domeny bogate $\mathrm{w}$ prolinę lub cysteinę, domeny DUF i LysM oraz domeny podobne do epidermalnego czynnika wzrostu (EGF). Również większość, bo aż 109 białek RLP rzodkiewnika w części wiążącej ligand ma domenę typu LRR [19,20]. Duża część poznanych dotychczas kinaz białkowych tworzących/współtworzących kompleksy receptorowe PRR roślin i wszystkie kinazy Pelle/IRAK zwierząt łączy jeden, przypuszczalnie ważny szczegół budowy, a mianowicie ten, że $\mathrm{w}$ subdomenie VI domeny kinazowej nie występuje motyw -RD- (reszta argininy i asparaginianu) $[4,21]$. Obecny u większości kinaz białkowych motyw -RDz resztą argininy hamuje aktywność katalityczną domeny kinazowej. Odblokowanie aktywności kinazowej następuje w wyniku fosforylacji tzw. pętli aktywacyjnej. Pojawiająca się tutaj reszta fosforanowa $\mathrm{z}$ ładunkiem ujemnym odciąga $\mathrm{z}$ centrum aktywnego dodatnio naładowaną resztę guainidynową argininy, co w efekcie prowadzi do odblokowania aktywności kinazowej. W kinazach białkowych typu PRR reszta argininy w motywie -RD- została zastąpiona innym aminokwasem, np. w AtFLS2 jest nim cysteina (Ryc. 1), co może sugerować, że funkcjonuje tu inny mechanizm aktywacji, bądź że kinazy te pozostają w stanie ciągłej aktywności. Brak motywu -RD- w kinazach PRR pozwala snuć pewne przypuszczenia odnośnie liczby kinaz białkowych typu RLK pośredniczących w percepcji cząsteczek MAMP/ PAMP/DAMP. Wyniki analiz bioinformatycznych wykazały, że genom rzodkiewnika zawiera 47 , a genom ryżu aż 371 genów kodujących receptorowe kinazy białkowe pozbawione motywu -RD- [21].

W odróżnieniu od kinaz białkowych typu RLK, które za odcinkiem transbłonowym mają domenę kinazową, białka RLP za helisą transbłonową mają tylko bardzo krótkie przedłużenie C-końcowe. W obrębie tego przedłużenia niektóre RLP mają motyw skierowujący do endocytozy, inne zaś mają motyw pośredniczący $\mathrm{w}$ wiązaniu białka $\mathrm{z}$ kotwicą glikozylofosfatydyloinozytolową (GPI). Ponadto, wyniki dotychczasowych badań pokazują, że białka RLP współtworzą heteromeryczne kompleksy $\mathrm{z}$ błonowymi kinazami białkowymi, a także z kinazami pochodzącymi z dwóch grup, a mianowicie SERK i SOBIR (patrz następne rozdziały) $[5,22,23]$.

\section{RECEPTORY WIĄŻĄCE CZĄSTECZKI MAMP/ PAMP POCHODZENIA BAKTERYJNEGO}

Cząsteczki MAMP/PAMP pochodzące z komórek bakterii można ogólnie podzielić na zewnątrzkomorkowe: (flagelina, białko budujące wić), cząsteczki budujące ściany i błony komórek bakteryjnych (peptydoglikan; PGN, lipopolisacharyd; LPS, permeaza ksantynowo-uracylowa; Xup) oraz cząsteczki pochodzenia wewnątrzkomórkowego (czynnik elongacyjny Ef-Tu, oligopeptyd RaxX, peptydy Csp22, Nlp20 i eMax). Na rycinie 2 pokazano wszystkie poznane dotychczas pary ligand-receptor, $\mathrm{w}$ których ligandami są cząsteczki MAMP/PAMP pochodzące z bakterii, a receptorami są poznane $\mathrm{W}$ różnych roślinach kompleksy receptorowe [3-5,24-26].

\section{Flagelina - kinaza AtFLS2 rzodkiewnika}

W doświadczeniach prowadzonych na kulturach komórkowych pomidora traktowanych zawiesinami bakterii Pseudomonas syringae pv. tabaci, ekstraktami bakteryjnymi oraz białkami izolowanymi z tych bakterii ujawniono po raz pierwszy, że czynnikiem aktywującym alkalizację środowiska zewnątrzkomórkowego i stymulującym produkcję aktywnych form tlenu jest flagelina - $33 \mathrm{kDa}$ białko budujące wić bakterii $[3,4]$. Flagelina pochodząca z różnych bakterii jest białkiem stosunkowo silnie zróżnicowanym, zarówno pod względem wielkości (28-50 kDa), jak również pod względem sekwencji aminokwasowej, chociaż w części N- i C-końcowej zauważalna jest wyraźna zachowawczość sekwencji. To właśnie w części N-końcowej flageliny położony jest 22-aminokwasowy aktywny epitop (flg22). Flagelina pochodząca z Agrobacterium, Rhizobium czy Xanthomonas o nieco odmiennej sekwencji w części N-końcowej nie wywołuje w komórkach pomidora efektów podobnych do flageliny z P.syringae. $\mathrm{W}$ podobnych doświadczeniach prowadzonych na 5-dniowych siewkach rzodkiewnika potwierdzono, że sam oligopeptyd

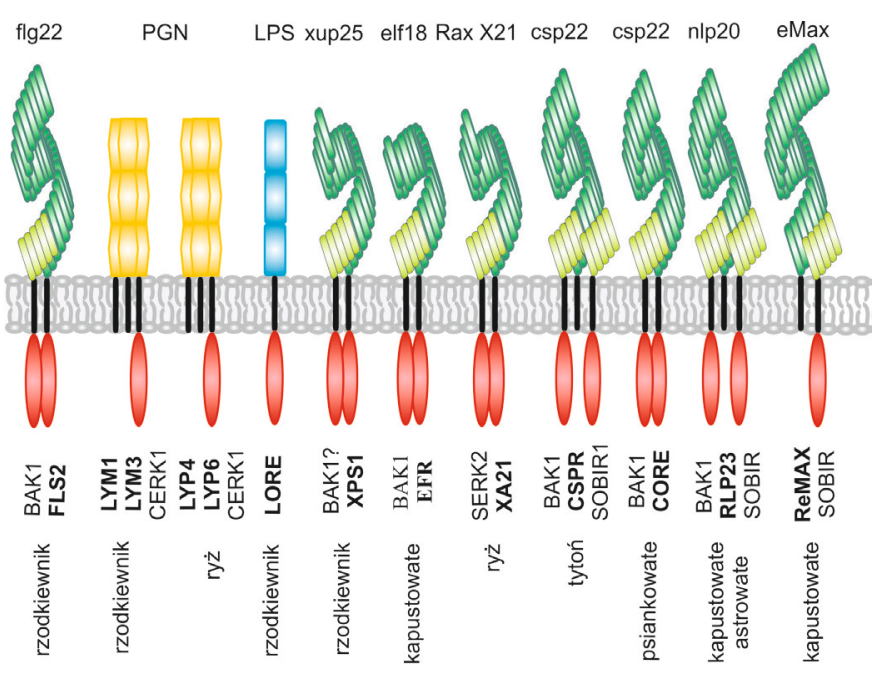

Rycina 2. Kompleksy receptorowe roślin wiążące cząsteczki MAMP/PAMP pochodzenia bakteryjnego. Szczegółowy opis w tekście (na podstawie prac $[4,5,21,24,25]$, zmieniono). 
flg22 hamuje wzrost siewek, aktywuje ekspresję genów $P R-1$ i PR-5 (ang. Pathogenesis-Related protein), stymuluje produkcję aktywnych form tlenu oraz aktywuje syntezę kalozy [3,4]. Efekt hamowania wzrostu siewek okazał się przydatny w selekcjonowaniu mutantów niewrażliwych na flg22. W ten sposób zidentyfikowano trzy mutanty fls2 (ang. flagellin-sensing2) rzodkiewnika, a niedługo potem wykazano, że wszystkie trzy mutacje dotyczą genu AtFLS2 kodującego 1173-aminokwasowe (129 kDa) białko (Ryc. 1) [17]. Domenę zewnątrzkomórkową AtFLS2 tworzy 28 powtórzeń 24-aminokwasowej sekwencji bogatej w leucynę (LRR). Ponadto w domenie zewnątrzkomórkowej występują dwa motywy cysteinowe i aż 18 motywów NxS/T będących potencjalnymi miejscami N-glikozylacji. Jak już wcześniej wspomniano, kinaza AtFLS2 w domenie kinazowej ma motyw -CD- zamiast ewolucyjnie zachowawczego motywu -RD-, a w odcinku położonym za domeną kinazową sekwencję podobną do PEST - motywu kierującego białka do ubikwitynylacji. Przeprowadzone przed czterema laty analizy krystalograficzne wykazały, że domena zewnątrzkomórkowa LRR tworzy strukturę solenoidu, a oligopeptyd flg22 działa jako „molekularny klej” umożliwiający powstawanie heterodimerycznego kompleksu razem z receptorową kinazą białkową AtBAK1, w którym ta ostatnia pełni funkcję koreceptora [27]. Analizy ekspresji genu AtFLS2 pokazały, że poziom jego ekspresji jest wyraźnie wyższy w komórkach szparkowych, hydatodach, korzeniach bocznych, wiązkach przewodzących, a także w miejscach zranienia liści [28]. Ponadto ujawniono, że ekspresja AtFLS2, a także poziom jego białkowego produktu są regulowane przez etylen, z drugiej zaś strony, powstawanie kompleksu AtFLS2/flg22/ AtBAK1 aktywuje syntezę etylenu [7].

Ortologami AtFLS2 poznanymi w innych roślinach są: NbFLS2 tytoniu, LeFLS2 pomidora, OsFLS2 ryżu, VvFLS2 winorośli [24,25]. Ponadto w nowszych badaniach wykazano, że flagelina $P$. syringae zawiera dwa epitopy, bo oprócz epitopu flg22 rozpoznawanego przez AtFLS2, w innym regionie występuje epitop flgII-28, który jest rozpoznawany przez kinazę receptorową FLS3 pomidora [29]. Co równie interesujące, w ryżu obok receptora OsFLS2 wiążącego flg22 występuje jeszcze inny nieznany receptor, który rozpoznaje epitop CD2-1 położony w części C-końcowej flageliny z Acidovorax avenae [30].

Peptydoglikany - heteromeryczne

kompleksy AtLYM1/LYM3/CERK1

Peptydoglikany (PGN) są składnikami ściany komórkowej bakterii zbudowanymi z N-acetyloglukozaminy łączącej się wiązaniami $\beta$-1,4-glikozydowymi z kwasem muraminowym (N-acetyloglukozamina połączona wiązaniem eterowym z kwasem mlekowym). Tworzące się w ten sposób długie łańcuchy polisacharydowe sieciowane są za pośrednictwem krótkich peptydów (zwykle tetrapeptydów) wiązanych poprzez reszty kwasu mlekowego z kwasem muraminowym (Ryc. 3). W bakteriach Gram-dodatnich, w pozycji trzeciej tetrapeptydów występuje zwykle L-lizyna, natomiast bakterie Gram-ujemne w tym miejscu mają kwas mezo-2,6-diaminopimelinowy (m-DAP) [31,32]. Peptydoglikany tworzą strukturę przypominającą woreczek otaczający komórkę bakteryjną i nadający bakterii określony kształt, a ponieważ PGN nie występują u eukariontów, dlatego założono, że fragmenty takiej sieci mogą pełnić funkcję cząsteczek MAMP/PAMP.

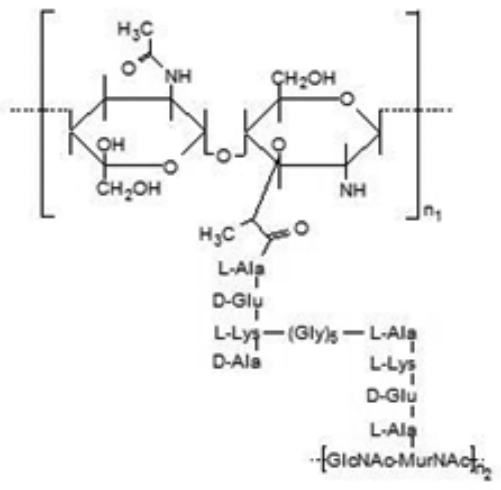

Rycina 3. Schemat budowy peptydoglikanów (PGN). Opis w tekście (na podstawie prac $[31,32])$.

Przypuszczenia te okazały się słuszne, bowiem w doświadczeniach sprzed dziesięciu lat prowadzonych na kulturach komórkowych tytoniu, a także $\mathrm{w}$ nowszych badaniach wykonywanych na kulturach komórkowych rzodkiewnika oraz liściach kilkutygodniowych roślin potwierdzono zakładaną rolę PGN. Peptydoglikany uzyskane z Staphylococcus aureus aktywują szereg szybkich odpowiedzi, takich jak: alkalizacja środowiska zewnątrzkomórkowego, napływ $\mathrm{Ca}^{2+}$ do cytoplazmy, synteza tlenku azotu, aktywacja kinaz MAP, synteza kamaleksyny. Podobne efekty obserwowano także w doświadczeniach prowadzonych na rzodkiewniku traktowanym PGN lub muropeptydami uzyskanymi z Gram-ujemnych patogennych bakterii Agrobacterium tumefaciens i Xanthomonas campestris [31].

W poszukiwaniach receptorów PGN od początku zwracano uwagę na białka zawierające charakterystyczne około 40-aminokwasowe sekwencje nazywane motywami LysM (nazwa nie pochodzi od aminokwasu lizyny, lecz od motywu znalezionego po raz pierwszy w bakteryjnym lizozymie, hydrolazie sekrecyjnej degradującej bakteryjne ściany komórkowe). W genomie rzodkiewnika zidentyfikowano 14 genów kodujących białka z pojedynczym, dwoma lub trzema motywami LysM. Pięć genów AtLYK 1-5 koduje kinazy białkowe typu LysM-RLK, a trzy geny kodują białka typu LysM-RLP (AtLYP1, AtLYP2/AtLYM3 i AtLYP3/ AtLYM1) [32]. Wyniki dotychczasowych badań prowadzonych na rzodkiewniku dowodzą, że w percepcji PGN pośredniczy heteromeryczny kompleks utworzony przez białka LysM-RLP (AtLYM1/AtLYP3 i AtLYM3/AtLYP2) oraz kinazę białkową AtLYK1/AtCERK1 (Ryc. 2) [33]. Białka AtLYM1 i AtLYM3 wiążą PGN, natomiast AtCERK1 pośredniczy w przekazywaniu sygnału do wnętrza komórki. W genomie ryżu zidentyfikowano sześć genów kodujących białka typu LysM-RLP (OsLYP1 do 6) z trzema motywami LysM. Wyniki nielicznych jeszcze badań sugerują, że heterodimer OsLYP4/OsLYP6 wiąże PGN, a także chitynę, a kinaza OsCERK1 przekazuje sygnał do wnętrza komórki [33].

Lipopolisacharydy - kinaza LORE rzodkiewnika

Lipopolisacharydy (LPS) są dużymi trzyczęściowymi cząsteczkami budującymi błonę zewnętrzną bakterii Gram-ujemnych. W skład LPS wchodzi lipid A, rdzeń oligosacharydowy i oligosacharyd-O (O-antygen) [31] (Ryc. 4). Czą- 


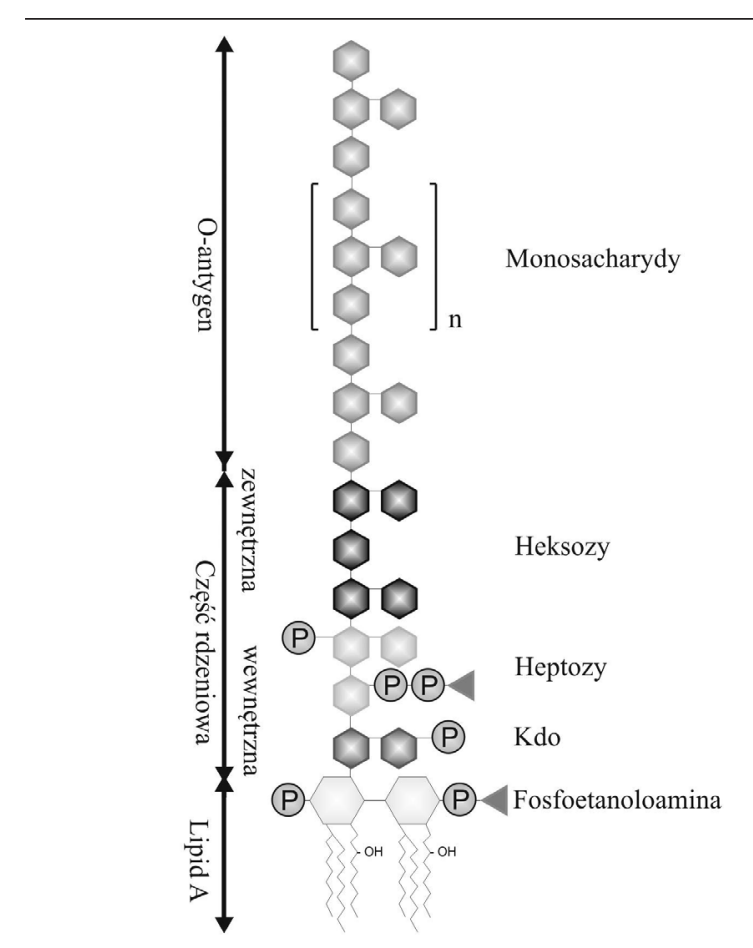

Rycina 4. Schemat budowy lipopolisacharydów (LPS). Opis w tekście (na podstawie pracy [31])

steczka LPS jest zakotwiczona w dwuwarstwie lipidowej za pośrednictwem lipidu A, który jest utworzony z części polarnej, zwykle D-glukozaminylo-D-glukozaminy. Cząsteczki glukozaminy $\mathrm{w}$ disacharydzie są podstawione $\mathrm{w}$ pozycjach 2 i 3 resztami kwasów tłuszczowych. Z lipidem A połączony jest za pośrednictwem wiązania ketozydowego oligosacharydowy rdzeń, w którym można wyróżnić region wewnętrzny zbudowany z 2-3 cząsteczek kwasu 2-keto-3-deoksyoktulozonowego (Kdo) i L-glicerolo-D-manno-heptoz. Region zewnętrzny rdzenia oligosacharydowego tworzą różne heksozy, z którymi połączony jest oligosacharyd-O zbudowany z powtarzających się podjednostek, utworzonych z 2-8 reszt cukrowcowych łączących się liniowo lub w sposób rozgałęziony [31].

Jak już wcześniej wspomniano, pierwszym poznanym receptorem typu TLR (ang. Toll-Like Receptor) u zwierząt jest białko TLR4 myszy pośredniczące $\mathrm{w}$ percepcji LPS. Wyniki pierwszych doświadczeń prowadzonych na kulturach komórkowych tytoniu pokazały, że LPS izolowany z X. campestris również $\mathrm{w}$ roślinach aktywuje reakcje odpornościowe, stymulując produkcję nadtlenku wodoru oraz napływ $\mathrm{Ca}^{2+}$ do cytoplazmy. W nowszych doświadczeniach, w których używano LPS uzyskiwanych $\mathrm{z}$ różnych bakterii potwierdzono aktywację szeregu innych wczesnych odpowiedzi typu PTI [31]. W doświadczeniach wykorzystujących LPS wyznakowany Alexa Fluor lub Qdot udało się w ostatnim czasie wykazać obecność na powierzchni protoplastów miejsc wiążących LPS [34]. Ostatecznie przed dwoma laty wyselekcjonowano mutanta rzodkiewnika niewrażliwego na LPS niezwykle podatnego na infekcję przez P. syringae [35]. Okazało się, że zmutowany gen koduje receptorową kinazę białkową LORE (ang. LipoOligosaccharide-Specific Reduced Elicitation), która w części zewnątrzkomórkowej ma domenę lektynową wiążącą lipid A. Na razie jeszcze nie wiadomo, czy w percepcji LPS u roślin biorą udział również inne białka, które, podobnie jak u zwierząt, pośredniczą w degradacji błony bakteryjnej (białko LBP) oraz przenoszą LPS (sCD14) na kompleks receptorowy TLR4/MD-2 [36].

Peptyd Xup25 - kinaza XPS1 rzodkiewnika

W poszukiwaniach nowych bakteryjnych cząsteczek typu MAMP/PAMP w Pseudomonas syringae zidentyfikowano sześć nowych peptydów. Szczegółowa analiza 25-aminkwasowego peptydu xup25 pochodzącego z permeazy ksantynowo-uracylowej zlokalizowanej w błonie bakteryjnej dowiodła, że xup25 pełni funkcję typowej cząsteczki MAMP/PAMP [37]. W percepcji xup25 pośredniczy podobna do AtFLS2 kinaza receptorowa XPS1 (ang. Xanthine/uracil Permease Sensing1), która w domenie zewnątrzkomórkowej zawiera 23 powtórzenia LRR [37].

Elf18 - kinaza AtEFR rzodkiewnika

W doświadczeniach prowadzonych na kulturach komórkowych rzodkiewnika traktowanych ekstraktami z Escherichia coli z delecją w genie FliC kodującym flagelinę, a także ekstraktami z bakterii pozbawionych wici (Ralstonia solanacearum, Sinorhizobium meliloti) wykazano, że komórki rzodkiewnika reagują na aplikowany ekstrakt podobnie jak na flagelinę, mimo że ekstrakty nie zawierają tego białka [38]. Aktywną cząsteczką okazało się $43 \mathrm{kDa}$ białko funkcjonujące w E. coli jako czynnik elongacyjny EF-Tu (ang. Elongation Factor-Tu). Z czasem wykazano, że jego aktywnym epitopem jest 18-aminokwasowy acetylowany N-końcowy oligopeptyd elf18. W doświadczeniach wykorzystujących wyznakowany izotopowo oligopeptyd elf26 udało się w błonach plazmatycznych rzodkiewnika zidentyfikować 150 kDa białko wiążące peptyd [3,4]. Oczyszczenie tego białka ułatwiło sklonowanie genu AtEFR (ang. EF-Tu Receptor) kodującego typową kinazę białkową RLK z 22 powtórzeniami LRR w części zewnątrzkomórkowej [3]. W tym miejscu warto jeszcze zwrócić uwage na wyniki niedawnych doświadczeń, w których wykazano, że w ryżu funkcjonuje niezidentyfikowany jeszcze receptor białka EF-Tu pochodzącego z Acidovorax evenae, który nie rozpoznaje epitopu elf18, lecz inny, położony w regionie środkowym epitop EFa50 [39].

Siarczanowany oligopeptyd RaxX21-sY z

Xanthomonas - kinaza XA21 ryżu

W badaniach związanych $\mathrm{z}$ odpornością ryżu na rdzę źdźbłową wywoływaną przez Xanthomonas oryzae pv. oryzae już w połowie lat dziewięćdziesiątych wyselekcjonowano i sklonowano gen OsXA21 kodujący receptorową kinazę białkową z 23 powtórzeniami typu LRR [4]. W poszukiwaniach cząsteczki PAMP pochodzącej z X. oryzae zidentyfikowano najpierw białko AX21, w którym aktywnym epitopem miał być 17-aminokwasowy oligopeptyd axYS 22 z siarczanowaną resztą tyrozyny [40]. Jednakże z czasem okazało się, że właściwą cząsteczką PAMP wiązaną przez OsXA21 jest 60-aminokwasowe białko RaxX, którego 21-aminokwasowy epitop zawiera siarczanowaną resztę tyrozyny [41]. Białko RaxX występuje u co najmniej ośmiu gatunków bakterii z rodzaju Xanthomonas infekujących wiele roślin uprawnych. $\mathrm{Na}$ marginesie badań związanych z kinazą XA21 warto zauważyć, iż mimo że cząsteczkę PAMP wiązaną przez 
OsXA21 zidentyfikowano dopiero przed dwoma laty, to jednak w ciągu trwających już ponad 22 lata badań udało się poznać cały szereg białek współtworzących i regulujących szlaki sygnałowe aktywujące odpowiedzi PTI [40].

Peptyd Csp22 - NbCSPR tytoniu i kinaza CORE pomidora

Wyniki doświadczeń sprzed czternastu lat ujawniły, iż 22-aminkwasowy epitop białka Csp (ang. Cold shock protein) z Micrococcus lysodeikticus aktywuje w tytoniu silne odpowiedzi typu PTI [42]. Małe białka szoku zimna (Csp) syntetyzują mikroorganizmy bytujące w środowisku o ustalonej niskiej temperaturze. $W$ takich warunkach są one niezbędne do uruchomienia i prawidłowego przebiegu transkrypcji i translacji, ponieważ umożliwiają $\mathrm{m}$. in. powstawanie funkcjonalnych rybosomów oraz likwidują w mRNA nietypowe struktury drugorzędowe powstające podczas szoku zimna. Białka Csp zawierają motywy RNP1 i RNP2 wiążące pojedynczą nić RNA lub DNA. W ubiegłym roku w doświadczeniach prowadzonych na tytoniu zidentyfikowano białko receptorowe NbCSPR (ang. RLP Required for CSP22 Responsiveness) typu RLP wiążące 22-aminokwasowy epitop położony obrębie motywu RNP1 [43]. Domena zewnątrzkomórkowa NbCSPR zawiera 28 powtórzeń LRR. Białko NbCSPR oddziałuje z kinazą NbSOBIR1, a w obecności csp22 tworzy heterokompleks zawierający także kinazę NbBAK1. W badaniach prowadzonych równolegle na pomidorze zidentyfikowano inne białko receptorowe wiążące peptyd csp22 [44]. Okazała się nim kinaza receptorowa CORE (ang. Cold Shock Protein Receptor) z powtórzeniami LRR w części zewnątrzkomórkowej.

Peptyd Nlp20 - AtRLP23 rzodkiewnika

W bakteriach, grzybach i lęgniowcach występują liczne białka tworzące dużą rodzinę białek NLP (ang. Necrosis and ethylene-inducing peptide1-like proteins), które u roślin wywołują nekrozy i aktywują produkcję etylenu [45]. Z czasem okazało się, że nie wszystkie białka NLP są toksyczne, a co bardziej interesujące, okazało się, że niektóre z nich pełnią funkcję cząsteczek typu PAMP. Szczegółowe analizy sekwencji aminokwasowej pokazały, że białka NLP łączy obecność 20-aminokwasowego zachowawczego motywu nlp20, który okazał się być właściwym epitopem wiązanym przez odpowiednie białko receptorowe. W doświadczeniach prowadzonych w ostatnim czasie wykazano, że w rzodkiewniku funkcję takiego receptora pełni białko typu RLP (AtRLP23) z 27 powtórzeniami LRR w części zewnątrzkomórkowej [46]. Białko RLP23 oddziałuje z kinazą białkową SOBIR1, a w obecności peptydu nlp20 tworzy kompleks receptorowy BAK1/nlp20/RLP23/SOBIR1.

Białko eMax - białko ReMAX typu RLP

W poszukiwaniach cząsteczek MAMP/PAMP produkowanych przez Xanthomonas axonopodis pv. citri, przed czterema laty udało się częściowo oczyścić frakcję białek określanych jako eMax (ang. enigmatic MAMP of Xanthomonas), które w rzodkiewniku i kilku innych roślinach $\mathrm{z}$ rodziny kapustowatych aktywuje syntezę etylenu [47]. Receptorem pośredniczącym w percepcji eMax okazało się białko Re-
MAX (ang. Receptor of eMax) typu RLP z 32 powtórzeniami LRR w części zewnątrzkomórkowej.

\section{RECEPTORY CZASTECZEK MAMP/PAMP POCHODZĄCYCH Z GRZYBÓW I LĘGNIOWCÓW}

W dotychczasowych poszukiwaniach cząsteczek MAMP/PAMP pochodzących z grzybów najwięcej uwagi poświęcono chitooligosacharydom, produktom degradacji chityny. Zidentyfikowano też kilka cząsteczek wewnątrzkomórkowych, takich jak: ksylanaza, poligalakturonazy, białko Ave, białko SCFE1. (Ryc. 5). Podobne do grzybów lęgniowce (Oomycete) mają ściany komórkowe zbudowane głównie z celulozy, a chityna występuje tu tylko w niewielkich ilościach. Patogenne lęgniowce, podobnie jak grzyby, wykazują charakter biotrofów, hemibiotrofów i nekrotrofów. Poznane w lęgniowcach cząsteczki MAMP/PAMP pochodzą głównie z hemibiotrofów z rodzaju Phytophthora oraz nekrotrofów z rodzaju Pythium [48].

Oligosacharydy chitynowe - heterokompleksy

białek z motywami LysM

Chityna jest polisacharydem zbudowanym z $N$-acetylo-D-glukozo-2-aminy połączonej wiązaniem $\beta$-1,4- glikozydowym. Chityna występuje u grzybów, stawonogów, niektórych bakterii oraz w osłonkach jaj nicieni. Cząsteczkami MAMP/PAMP pochodzącymi z chityny są oligosacharydy uwalniane $\mathrm{z}$ łańcuchów chitynowych przez chitynazy zlokalizowane w apoplaście roślin [49,50]. Pierwsze próby identyfikowania w roślinach białek wiążących chitynę podejmowano już w latach dziewięćdziesiątych ubiegłego wieku, lecz dopiero w połowie ubiegłego dziesięciolecia z błon plazmatycznych ryżu wyizolowano i oczyszczono białko OsCEBiP (ang. Chitin oligosaccharide Elicitor-Binding Protein), a następnie sklonowano kodujący go cDNA. OsCEBiP jest jednym z sześciu białek typu RLP (CEBiP/OsLYP1 i OsLYP2 do 6) zawierających po trzy motywy LysM [32]. W części C-końcowej OsCEBiP oraz trzech innych białek z tej samej podrodziny występują sekwencje wiążące białko do kotwicy glikozylofosfatydyloinozytolowej (GPI). Szczegółowe analizy wykazały, że chitooligosacharyd zawierający 7/8 jednostek N-acetyloglukozoaminy wiązany jest przez homodimer OsCEBiP, natomiast białkiem przekazującym sygnał do wnętrza komórki jest kinaza białkowa OsCERK1 współtworząca $\mathrm{z}$ dimerem OsCEBiP/CEBiP kompleks receptorowy (Ryc. 5) [49,50]. Na razie nie potwierdzono jeszcze wcześniejszych sugestii, jakoby w ryżu w percepcji chitooligosacharydów brały udział także białka OsLYP4 i OsLYP6 wiążące PGN [33].

W poszukiwaniach receptora chitooligosacharydów w rzodkiewniku w pierwszej kolejności przeanalizowano mutanty z defektami w genach kodujących białka z motywami LysM, u których po aplikacji chitooligosacharydu nie obserwowano rosnącej produkcji aktywnych form tlenu. Mutantem całkowicie niewrażliwym na oligosacharyd chitynowy okazał się mutant $\mathrm{z}$ defektem $\mathrm{w}$ genie kodującym receptorową kinazę białkową AtCERK1 (ang. Chitin Elicitor Receptor Kinase 1) z trzema motywami LysM w części zewnątrzkomórkowej [49,50]. Jak już wcześniej wspomniano, genom rzodkiewnika oprócz AtCERK1/LYK1 zawiera jeszcze cztery geny kodujące kinazy typu LysM-RLK oraz trzy 


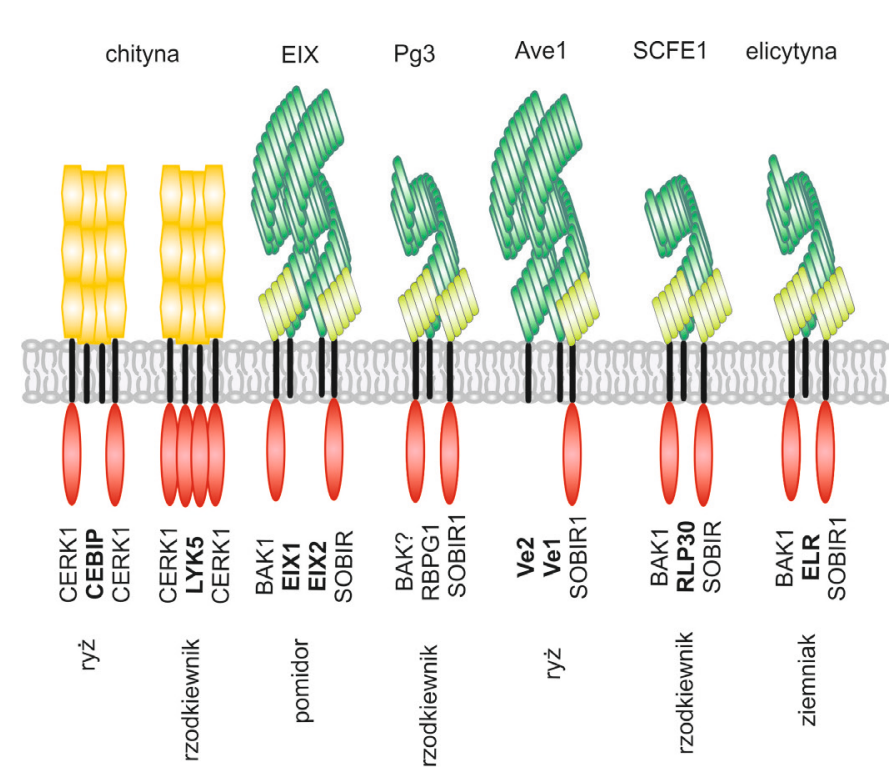

Rycina 5. Kompleksy receptorowe roślin wiążące cząsteczki MAMP/PAMP grzybów i lęgniowców. Szczegółowy opis w tekście (na podstawie prac $[4,5,21,24,25,50]$, zmieniono).

geny kodujące białka podobne do OsCEBiP ryżu. Poznanie budowy kompleksu receptorowego w ryżu, skłaniało do przypuszczeń, że również w rzodkiewniku kompleksem receptorowym może być heteromeryczny kompleks typu LysM-RLK/LysM-RLP. Ostatecznego potwierdzenia powyższych sugestii dostarczyły badania sprzed trzech lat, w których wykazano, że w rzodkiewniku chitooligosacharyd wiązany jest przez homodimer utworzony przez pseudokinazę białkowa AtLYK5 z nieaktywną domeną kinazową, natomiast $\mathrm{w}$ przekazywaniu sygnału do wnętrza komórki pośredniczy AtCERK1 [51]. Tak więc, homodimer AtLYK5/ LYK5 w kompleksie receptorowym rzodkiewnika odgrywa podobną rolę jak homodimer OsCEBiP/CEBiP w ryżu (Ryc. 5).

Wyniki pojedynczych doniesień, sugerują, że w rzodkiewniku funkcjonuje jeszcze inny kompleks receptorowy chitooligosacharydów zlokalizowany w błonach plazmodesm, który jest utworzony przez białko AtLyM2 typu RLP współdziałające $\mathrm{z}$ niezidentyfikowaną jeszcze kinazą białkową, inną niż AtCERK1 [49,50].

Ksylanaza (EIX) - białka LeEIX1/2 pomidora

Pod koniec lat osiemdziesiątych w patogennym grzybie Trichoderma viride zidentyfikowano białko EIX (ang. Ethylene-inducing Xylanase), które w liściach tytoniu i pomidora aktywuje syntezę etylenu [4]. Białko EIX okazało się być 22 kDa endoksylanazą hydrolizującą liniowe wiązania glikozydowe typu $\beta-1,4$ ksylanu, dając podstawione lub niepodstawione produkty (ksylobioza, ksyloza). W nowszych badaniach jednoznacznie wykazano, że w aktywacji biosyntezy etylenu i innych reakcji typu PTI nie biorą udziału produkty hydrolizy chemiceluloz, ponieważ aktywacja PTI zachodzi również wówczas, gdy EIX jest pozbawiona aktywności katalitycznej. W połowie ubiegłego dziesięciolecia w pomidorze zidentyfikowano i sklonowano dwa geny Le-
EIX1 i LeEIX2 kodujące białka typu RLP wiążące EIX [52]. Oba białka LeEIX są stosunkowo dużymi glikoproteinami zawierającymi w części zewnątrzkomórkowej 31 powtórzeń LRR, a w krótkich odcinkach cytoplazmatycznych mają charakterystyczne motywy kierujące białka do endocytozy. Wyniki najnowszych badań wykazały, że w wiązaniu ksylanazy EIX pośredniczy dimer LeEix1/2, w którym LeEIX1 oddziałuje z kinazą białkową BAK1. Wiązanie EIX do kompleksu receptorowego kieruje do endocytozy białko LeEIX2, które następnie w błonach wczesnych endosomów aktywuje szlak sygnałowy [53].

Endopoligalakturonaza BcPG3 - białko RBPG1/AtRLP42 rzodkiewnika

Grzyby patogenne syntetyzują enzymy hydrolityczne, w tym również endopoligalakturonazy (PG) hydrolizujące pektyny, polisacharydy zbudowane z cząsteczek kwasu D-galakturonowego połączonych wiązaniami $\alpha$-1,4-glikozydowymi. Grzyb nekrotroficzny Botrytis cinerea zawiera sześć genów BcPG kodujących endopoligalakturonazy aktywujące w winorośli reakcje odpornościowe typu PTI. Wyniki szczegółowych badań wykazały, że aktywność immunogenna niektórych endopoligalakturonaz nie jest powiązana $z$ ich aktywnością enzymatyczną [54]. Przed paru laty $\mathrm{w}$ badaniach prowadzonych na rzodkiewniku udało się zidentyfikować białko receptorowe RBPG1 (ang. Responsiveness to Botrytis Polygalacturonase1) typu RLP (AtRLP42) wiążące BcPG3. Białko AtRBPG1/RLP42 oddziałuje z kinazą SOBIR1, a przypuszczalnie także z BAK1 (Ryc. 5) [55].

Białko Ave1 z Verticillium - Ve1 pomidora

Grzyby z rodzaju Verticillium, zwłaszcza $V$. dahliae i $V$. albo-atrum, wywołują chorobę nazywaną wertycyliozą polegającą na tym, że strzępki grzybów wrastają do korzenia poprzez włośniki lub zranienia i opanowują wiązki naczyniowe. Zainfekowanie grzybem prowadzi do zablokowania drożności naczyń i zamierania rośliny. Wertycylioza jest chorobą występującą u ponad 200 gatunków roślin dwuliściennych, w tym także $u$ wielu roślin uprawnych. Od ponad szesnastu lat było wiadomo, że odporność niektórych odmian roślin uprawnych na wertycyliozę, w tym $\mathrm{m}$. in. pomidora na $V$. dahliae, powiązana jest z locus $V e$, który obejmuje dwa geny $V e 1$ i $V e 2$ [56]. W pomidorze oba geny kodują stosunkowo duże glikoproteiny typu RLP z 38 powtórzeniami LRR w części zewnątrzkomórkowej. Odcinek cytoplazmatyczny obu białek zawiera motyw skierowujący je do endocytozy, a Ve2 ma dodatkowo sekwencję PEST destabilizującą białko. W aktywacji odpowiedzi obronnych białko Ve1 współdziała z kinazą SOBIR. Jedenaście lat po poznaniu białek Ve1/2 udało się wreszcie zidentyfikować cząsteczkę PAMP pochodzącą z Verticillium. Okazało się nią 134-aminokwasowe białko sekrecyjne Ave1 (ang. Avirulence on Ve1 tomato), którego sekwencja aminokwasowa jest podobna do sekwencji peptydu natriuretycznego roślin [57].

Białka SCFE1 - AtRLP30 rzodkiewnika

Prawie 400 gatunków roślin, w tym również wiele uprawnych, atakuje twardnica pasożytnicza (Sclerotinia sclerotiorum), grzyb nekrotroficzny wywołujący zgniliznę twar- 
dzikową. W doświadczeniach, których celem było zidentyfikowanie $\mathrm{w}$ ekstrakcie białkowym otrzymanym $\mathrm{z}$ kultury S. sclerotiorum cząsteczki typu PAMP udało się częściowo oczyścić frakcję białek SCFE1 (ang. Sclerotinia Culture Filtrate Elicitor1) o masie cząsteczkowej 16-22 kDa, która aplikowana na liście rzodkiewnika aktywuje syntezę etylenu [58]. W percepcji SCFE1 pośredniczy białko receptorowe AtRLP30 z domena zewnątrzkomórkową zawierającą 21 powtórzeń LRR. Białko AtRLP30 oddziałuje z AtBAK1 i AtSOBIR1 i aktywuje w rzodkiewniku reakcje odpornościowe skierowane przeciwko, co najmniej dwóm grzybom nekrotroficznym [58].

\section{Elicytyny lęgniowców - białko ELR ziemniaka}

Elicytyny to małe białka sekrecyjne lęgniowców z rodzaju Phytophthora i Pythium kodowane przez dużą rodzinę genów dzielonych na 17 grup (4 grupy elicytyn; ELI i 13 grup białek podobnych do elicytyn; ELL) [59]. Elicytynami są białka, takie jak: kryptogeiny, kapsiceiny, parasytycyny, białka INF1. Wszystkie biała z tej rodziny mają 98-aminokwasową domenę zawierającą 6 reszt cysteiny o sekwencji zachowanej w ewolucji. Elicytyny wiążą sterole i inne lipidy, a ponieważ nie wykazują homologii z sekwencjami aminokwasowymi białek roślinnych, dlatego od wielu lat były uważane za potencjalne cząsteczki PAMP. Przed dwoma laty $\mathrm{w}$ dziko rosnącym ziemniaku (Solanum microdontum) poznano białko receptorowe ELR (ang. Elicitin Response) typu RLP z domeną zewnątrzkomórkowa typu LRR [60]. Okazało się, że białko ELR współtworzy z kinazami BAK1 i SOBIR1 kompleks receptorowy rozpoznający zachowawczy epitop elicytyn pochodzących z kilku gatunków Phytophthora (Ryc. 5).

Oprócz elicytyn, w lęgniowcach zidentyfikowano jeszcze co najmniej kilka innych cząsteczek typu PAMP, chociaż białek receptorowych rozpoznających te cząsteczki na razie nie znamy. Można tu wymienić cząsteczki takie jak: peptyd Pep-13 pochodzący z transglutaminazy błonowej P. sojae, białko sekrecyjne OPEL z P. parasitica, białko CBEL wiążące celulozę z P. parasitica, a także $\beta$-glukany z P. sojae, czy 20-węglowy kwas arachidonowy z P. infestans [48].

\section{RECEPTORY WIĄŻĄCE CZĄSTECZKI TYPU DAMP}

Cząsteczki typu DAMP (ang. Damage/Danger-Associated Molecular Pattern) pochodzą z rośliny atakowanej przez patogeny, uszkodzonej mechanicznie lub zranionej przez roślinożerców. Są one dzielone na cząsteczki DAMP typu pierwotnego, takie jak: oligogalakturonidy (OG), zewnątrzkomórkowy ATP (eATP), NAD(P), celobioza oraz cząsteczki typu wtórnego, takie jak: AtPep, AtPIP, systemina i szereg innych peptydów wycinanych z probiałek [61]. Na rycinie 6 pokazano cztery poznane receptorowe kinazy białkowe pośredniczące w percepcji OG, eATP, AtPep i AtPIP.

Oligogalakturonidy - kinaza WAK1 rzodkiewnika

Aktywne oligogalakturonidy są oligomerami kwasu D-galakturonowego pochodzącymi z częściowej degradacji homogalakturonanów (HG) stanowiących około $65 \%$ struktury pektyn. W degradacji łańcuchów homogalakturonano-

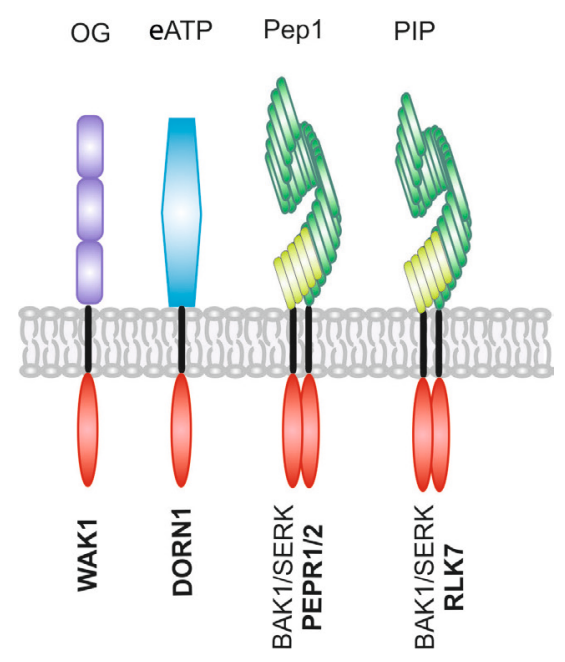

Rycina 6. Kinazy receptorowe rzodkiewnika wiążące cząsteczki typu DAMP. Szczegółowy opis w tekście (na podstawie prac [5,61,62,64], zmieniono).

wych biora udział endopoligalakturonazy patogenów oraz poligalakturonazy pochodzące $\mathrm{z}$ atakowanej rośliny. Cząsteczkami aktywnymi są oligomery zbudowane z 9-15 reszt deestryfikowanego kwasu galakturonowego, które dzięki licznym ładunkom ujemnym przy C-6 kwasu galakturonowego tworzą powiązane jonami wapnia formy dimeryczne określane jako „egg box" [62]. Oligogalakturonidy są wiązane przez błonową receptorową kinazę białkową WAK1, która w części zewnątrzkomórkowej ma motywy podobne do epidermalnego czynnika wzrostu EGF. W rzodkiewniku WAK1 jest jedną z pięciu kinaz białkowych z rodziny WAK (ang. Wall-Associated Kinase). Kinazy WAK1/2 wiążą pektyny ścian komórkowych i dlatego ich funkcję wiązano początkowo z regulacją wzrostu elongacyjnego komórek. Z czasem okazało się, że co najmniej AtWAK1 rzodkiewnika i OsWAK1 ryżu wiążą oligogalakturonidy i aktywują reakcje odpornościowe typu PTI [62,63].

Zewnątrzkomórkowy ATP (eATP) -

kinaza DORN1 rzodkiewnika

Wyniki stosunkowo licznych już badań pokazują, że szereg czynników abiotycznych i biotycznych może powodować wzrost stężenia ATP w przestrzeni zewnątrzkomórkowej roślin [64]. Ponadto $\mathrm{w}$ wielu interesujących doświadczeniach wykazano udział zewnątrzkomórkowego ATP w regulacji niektórych procesów wzrostu i rozwoju roślin. W poszukiwaniach receptora eATP wyselekcjonowano dwa alleliczne mutanty dorn (ang. does not respond to nucleotides) rzodkiewnika, u których aplikacja egzogennego ATP nie pociąga zmian w napływie jonów $\mathrm{Ca}^{2+}$ do cytoplazmy [65]. Okazało się, że wyselekcjonowane mutanty mają zmieniony gen kodujący błonową receptorową kinazę białkową LecRK-I.9, która w części zewnątrzkomórkowej wiążącej ATP ma domenę lektynową, podobną do lektyn roślin strączkowych [65]. Kinaza DORN1/LecRK-I.9 wiąże ATP oraz inne nukleotydy purynowe, natomiast nie wiąże adenozyny czy CTP. Analizy porównawcze zmian w ekspresji genów aktywowanych przez eATP i zmian towarzyszących zranieniu tkanki wykazały, że w obu przypadkach ekspresja około 60\% genów ulega podobnym zmianom [64]. 
Oligopeptydy AtPep1- kinazy PEPR1 i PEPR2 rzodkiewnika

$\mathrm{W}$ licznych badaniach analizujących odpowiedzi roślin na różne czynniki stresowe, przed ponad dziesięciu laty $\mathrm{w}$ rzodkiewniku poznano rodzinę ośmiu genów PROPEP kodujących białka zbudowane z 75-109 reszt aminokwasowych, których ekspresja znacząco rośnie w warunkach zranienia, ataku fitopatogenów, a także jako efekt traktowania rośliny jasmonianem lub etylenem [66]. Polipeptydy PROPEP w części C-końcowej mają 23-aminokwasowy zachowany w ewolucji motyw, który wycięty z propeptydu pełni funkcję cząsteczki DAMP. Aplikacja oligopeptydu AtPep1 na liście rzodkiewnika powoduje wzrost syntezy nadtlenku wodoru i aktywuje ekspresję genów związanych z odpornością. W percepcji oligopeptydów AtPep biorą udział dwie kinazy białkowe typu LRR-RLK, a mianowicie AtPEPR1 i AtPEPR2 (ang. Pep Receptor1/2). Obie kinazy w części zewnątrzkomórkowej mają po 25 powtórzeń typu LRR, a w części wewnątrzkomórkowej w obrębie domeny kinazowej zawierającej motyw -RD- występuje jeszcze motyw cyklazy guanylanowej [66]. AtPEPR1 wiąże wszystkie osiem oligopeptydów, natomiast AtPEPR2 rozpoznaje tylko AtPep1 i AtPep2. Analiza struktury krystalicznej domeny LRR receptora AtPEPR1 pokazała, że wiązanie AtPep1 zachodzi na wewnętrznej powierzchni solenoidu, a kinaza AtBAK1 pełni funkcje koreceptora [67]. W ostatnim czasie potwierdzono doświadczalnie podwójną aktywność AtPEPR1 wykazując, że aktywacji kinazy towarzyszy zarówno fosforylacja cytoplazmatycznej kinazy białkowej BIK1, jak również synteza cGMP aktywującego napływ $\mathrm{Ca}^{2+}$ do cytoplazmy [66].

Peptyd PIP1 - kinaza RLK7 rzodkiewnika

W poszukiwaniach nowych peptydów typu DAMP zwrócono uwagę na rodzinę 11 genów, których ekspresja w rzodkiewniku jest aktywowana przez flg22, chitynę oraz patogenne bakterie i grzyby. Kodowane 70-110-aminokwasowe preprobiałka prePIP (ang. precursors of PAMP-Induced Peptide) w części C-końcowej mają 13-aminokwasową zachowawczą sekwencję z motywem -SGP-, w którym reszta proliny ulega hydroksylacji [68]. Wykazano, że aplikacja syntetycznych peptydów PIP1 i PIP2 aktywuje w rzodkiewniku ekspresję wielu genów związanych z odpornością oraz szereg innych odpowiedzi typu PTI. Białkiem receptorowym wiążącym PIP1 jest receptorowa kinaza białkowa AtRLK7 z powtórzeniami LRR w części zewnątrzkomórkowej, a w aktywacji szlaku sygnałowego, a przypuszczalnie także w wiązaniu PIP1 bierze udział również kinaza AtBAK1 [68].

\section{AKTYWACJA I REGULACJA SZLAKÓW SYGNAŁOWYCH INICJUJĄCYCH ODPOWIEDZI OBRONNE}

\section{BIAŁKA ODDZIAŁUJACCE Z RECEPTORAMI PRR}

Aktywacja i regulacja szlaków sygnałowych zachodzi w błonie już na etapie formowania kompleksu receptorowego wiążącego cząsteczki MAMP/PAMP/DAMP i obejmuje zmiany w oddziaływaniach białka receptorowego z wieloma innymi białkami błonowymi oraz białkami wewnątrzkomórkowymi. Obecna wiedza na temat formowania i regulacji kompleksów receptorowych pochodzi głównie z badań poświęconych kinazom AtFLS2, AtEFR1, AtPEPR1 rzodkiewnika [6,24-26,69] i kinazie OsXA21 ryżu [40]. Wyniki tych badań wykazały, że w warunkach braku liganda, kinaza funkcjonująca jako receptor typu PRR i kinaza koreceptorowa BAK1 (ang. BRI1-Associated Kinase 1), jedna z pięciu kinaz rodziny SERK (SERK1, SERK2, SERK3/BAK1, SERK4/BKK1 i SERK5) (ang. Somatic Embryogenesis Receptor Kinase), zajmują w błonie oddzielne mikrodomeny [70]. Obie kinazy w takich warunkach oddziałują $\mathrm{z}$ innymi białkami. Kinaza BAK1 oddziałuje z pseudokinazą BIR2 lub jej paralogami BIR1 i BIR3, tworząc heterodimery stanowiące pulę zapasową BAK1 lub, jak sugerują inne wyniki, funkcjonujące $w$ regulacji autoimmunizacji (Ryc. 7) [22,71]. Kinaza AtFLS2 oddziałuje z kilkoma kinazami receptorowymi (FERONIA, IOS1, CRK28, LecRK-VI.2), których funkcja nie została jeszcze dokładnie poznana, a także $\mathrm{z}$ oksydazą NADPH, z dużym białkiem G (XLG2) i z Ca ${ }^{2+}$-ATPazami (ACA8 i ACA10) pompującymi jony wapnia z cytoplazmy do apoplastu $[6,69]$.

$\mathrm{W}$ wielu dotychczasowych badaniach wykazano jednoznacznie, że wraz z pojawieniem się odpowiedniej cząsteczki MAMP/PAMP lub DAMP, kinaza BAK1 oddysocjowuje od BIR, by utworzyć kompleks receptorowy z kinazami AtFLS2, AtEFR, AtPEPR1, AtRLK7 i SlCORE (Ryc. 7) [22,71]. Ponadto wyniki najnowszych badań pokazują, że kinaza BAK1, lub niektóre inne kinazy z rodziny SERK, tworzą funkcjonalne kompleksy receptorowe $\mathrm{z}$ białkami typu RLP (Eix1/2, Ve1/2, RLP23, RLP30, ELR), które w warunkach braku liganda występują $\mathrm{w}$ formie heterodimerów $\mathrm{z}$ pseudokinazą SOBIR1 pełniącą funkcję białka adaptorowego $[6,23,69]$. Co więcej, w najnowszych badaniach ujawniono, że kompleksy receptorowe wiążące peptydy sygnałowe IDA, PSK, RGF, TDIF również są współtworzone przez odpowiednie kinazy białkowe (HAESA, PSKR1, RGFR1, PXY) i kinazę koreceptorową BAK1[6,22].

Jak już wcześniej wspomniano, domena wewnątrzkomórkowa kinazy AtFLS2 i kinazy AtBAK1 oddziałuje z niektórymi kinazami cytoplazmatycznymi (BIK1, BSK1, PBL) typu RLCK (ang. Receptor Like Cytoplasmic Kinase) przekazującymi sygnał z kompleksu receptorowego na różne białkowe elementy szlaków sygnałowych (Ryc. 7) [6,69,72-74]. Utworzenie aktywnego kompleksu AtFLS2/flg22/AtBAK1 prowadzi do fosforylacji przez AtBAK1 kinazy AtBIK1, która następnie fosforyluje AtFLS2 i AtBAK1. Aktywowana w ten sposób kinaza AtBIK1, a także inne kinazy RLCK, fosforylują m. in.: oksydazę NADPH, kinazy MAPKKK, duże białko G (XLG2), a przypuszczalnie także kanały $\mathrm{Ca}^{2+}[6,69]$ (patrz następne podrozdziały). Ponadto wykazano, że kinaza AtBAK1 fosforyluje ligazy ubikwitynowe typu U-box (PUB12 i PUB13), które ubikwitynylują kinazę AtFLS2, a przypuszczalnie także inne receptory typu PRR. Wyznakowana ubikwityną kinaza AtFLS2 ulega endocytozie zależnej od klatryny i jest kierowana do wakuoli litycznych, gdzie ulega degradacji proteolitycznej [6,69]. W ten sposób następuje czasowe odwrażliwienie układu odpornościowego na aktywację przez flg22. Ponadto wykazano, że kinazy AtBAK1 i AtBIK1 podlegają negatywnej regulacji przez fosfatazy białkowe PP2A i PP2C38, a fosforylacja AtBIK1 przez kinazę CPK28 aktywowaną przez $\mathrm{Ca}^{2+}$ kieruje ją do degradacji w proteasomach $[6,69,72]$. 


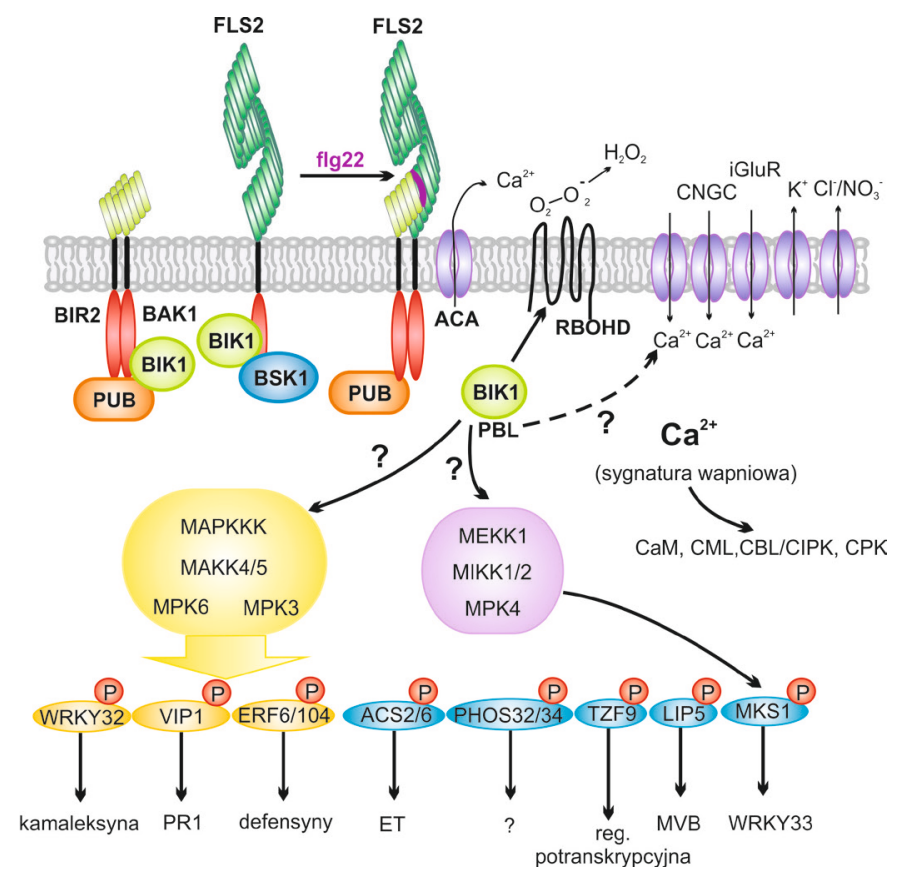

Rycina 7. Szlaki sygnałowe aktywowane przez kompleks receptorowy AtFLS2/ AtBAK1 wiążący flagelinę. Szczegółowy opis w tekście (na podstawie prac $[6,7,72,74]$, zmieniono).

Sygnał przekazywany z kompleksu receptorowego do wnętrza komórki za pośrednictwem kinaz RLCK lub bezpośrednio na białka współtworzące szlaki sygnałowe aktywuje wewnątrz komórki szereg szybkich reakcji, spośród których na szczególną uwagę zasługują zmiany, takie jak: napływ $\mathrm{Ca}^{2+}$ do cytoplazmy, produkcja aktywnych form tlenu i synteza NO oraz aktywacja kaskad kinaz MAP (Ryc. 7) $[6,7,69,72,74]$.

\section{GENEROWANIE I ROZKODOWYWANIE \\ SYGNATURY WAPNIOWEJ W CYTOPLAZMIE}

Już w latach dziewięćdziesiątych ubiegłego wieku wykazano doświadczalnie, że jedną z tzw. szybkich odpowiedzi na różne elicytory (kryptogeina, harpina, oligogalakturonid, peptyd Pep-3, $\beta$-glukan) jest wzrost stężenia $\mathrm{Ca}^{2+}$ w cytoplazmie, obserwowany już po 30-120 s od aplikacji elicytora [3]. Napływowi jonów $\mathrm{Ca}^{2+}$ do cytoplazmy towarzyszy wypływ z komórki jonów $\mathrm{K}^{+}, \mathrm{Cl}^{-}, \mathrm{NO}_{3}$ - oraz zahamowanie pompowania $\mathrm{H}^{+}$przez $\mathrm{H}^{+}$-ATPazę. Prowadzi to do alkalizacji środowiska zewnątrzkomórkowego (po 60s) i depolaryzacji błony (po 1-3 min) [7,69]. Napływ jonów $\mathrm{Ca}^{2+} \mathrm{z}$ apoplastu i generowanie w cytoplazmie określonej sygnatury wapniowej, odmiennej dla różnych cząsteczek MAMP/ PAMP/DAMP, stało się $\mathrm{W}$ ostatnim czasie przedmiotem szczegółowych analiz $[75,76]$. Sygnatura wapniowa obejmuje kształt pików wapniowych, amplitudę, częstotliwość oraz lokalizację subkomórkową i tkankową. W generowaniu określonej sygnatury muszą współdziałać odpowiednie kanały wapniowe, białka nośnikowe oraz pompy transportujące jony $\mathrm{Ca}^{2+} \mathrm{z}$ powrotem do właściwych przedziałów magazynujących.

Na razie nie są jeszcze znane kanały wapniowe, których aktywacja byłaby bezpośrednio powiązana $\mathrm{z}$ aktywacją kompleksów receptorowych wiążących cząsteczki MAMP/ PAMP/DAMP, chociaż wyniki pojedynczych doświadczeń prowadzonych na mutantach pbl1 i bik1 sugerują, że w ich aktywacji mogą pośredniczyć niektóre kinazy RLCK [77]. Ponadto $\mathrm{w}$ doświadczeniach prowadzonych na ryżu wykazano, że kompleks receptorowy wiążący chitynę oddziałuje bezpośrednio z aneksyną ANN1, która nie tylko wiąże, ale również transportuje przez błonę jony $\mathrm{Ca}^{2+}$. Przypuszcza się także, że aktywacja kanałów wapniowych odbywa się z udziałem aktywnych form tlenu, podobnie jak to ma miejsce w przypadku aneksyny [75].

W poszukiwaniach białek transportujących jony wapnia uwaga badaczy koncentruje się głównie na kanałach regulowanych przez cykliczne nukleotydy, kodowanych w rzodkiewniku przez 20 genów CNGC (ang. Cyclic Nucleotide Gated Channel) [75,76]. Badania te nabierają szczególnego znaczenia w kontekście doświadczeń związanych z kinazą białkową AtPEPR1, która w domenie kinazowej ma motyw cyklazy nukleotydowej i może syntetyzować cGMP [66]. Wyniki innych badań dowodzą, że w generowaniu określonej sygnatury wapniowej biorą udział również kanały jonowe bramkowane aminokwasami iGluR (ang. ionotropic Glutamate Receptor-like channels). Genom rzodkiewnika zawiera co najmniej 20 genów kodujących białka podobne do zwierzęcych kanałów glutaminianowych iGluR [75,76]. W usuwaniu $\mathrm{Ca}^{2+}$ z cytoplazmy biorą udział co najmniej dwie $\mathrm{Ca}^{2+}$-ATPazy (ACA8 i ACA10) oddziałujące z AtFLS2. W ostatnim czasie potwierdzono doświadczalnie udział obu tych $\mathrm{Ca}^{2+}$-ATPaz w aktywacji wczesnych odpowiedzi na flg22 [75].

W rozkodowywaniu charakterystycznego wzorca zmian stężenia $\mathrm{Ca}^{2+} \mathrm{w}$ cytoplazmie pośredniczy w roślinach szereg białek sensorowych, w tym $\mathrm{m}$. in. kalmodulina (CaM), białka podobne do kalmoduliny (CML), białka podobne do zwierzęcej kalcyneuryny B (CBL) aktywujące kinazy białkowe CIPK oraz kinazy białkowe aktywowane przez $\mathrm{Ca}^{2+}$ (CPK) $[7,69,75,76]$. W dotychczasowych poszukiwaniach białek sensorowych funkcjonujących w aktywacji reakcji obronnych najwięcej uwagi poświecono białkom CPK (ang. $\mathrm{Ca}^{2+}$-dependent Protein Kinase), w rzodkiewniku kodowanym przez 34 geny. Wykazano doświadczalnie, że w szlaku sygnałowym aktywowanym przez flg22 biorą udział co najmniej cztery kinazy z tej rodziny, a mianowicie AtCPK4, 11, 5,6 . W innych, niezbyt licznych jeszcze badaniach wykazano, że w aktywacji PTI biorą także udział: kalmodulina, białko kalmodulinopodobne CML9 oraz kinazy CIPK zależne od białek CBL.

\section{PRODUKCJA AKTYWNYCH FORM TLENU I TLENKU AZOTU}

Wzrost stężenia jonów wapnia w cytoplazmie aktywuje w apoplaście produkcję przez oksydazę NADPH anionorodników ponadtlenkowych przekształcanych samorzutnie bądź z udziałem dysmutaz ponadtlenkowych do nadtlenku wodoru. Genom rzodkiewnika koduje dziesięć enzymów błonowych RBOH (ang. Respiratory Burst Oxidase Homolog) z dwiema domenami EF-hand wiążącymi $\mathrm{Ca}^{2+}$ oraz motywami, które mogą być fosforylowane przez kinazy białkowe [78]. Wyniki szeregu badań pokazują, że w aktywacji reakcji odpornościowych typu PTI bierze udział oksydaza 
RBOHD, która może być fosforylowana przez cytoplazmatyczną kinazę BIK1 aktywowaną przez receptory PRR, a także przez zależne od jonów wapnia kinazy CPK (CPK4, CPK5, CPK6 i CPK11) zawierające domenę podobną do kalmoduliny (Ryc. 7). Produkcję anionorodników ponadtlenkowych reguluje także duże białko G (XLG2) oddziałujące $\mathrm{z}$ AtFLS2 [78-80] oraz aktywowana przez MAMP/PAMP kinaza ASK $\alpha$ fosforylująca cytoplazmatyczą dehydrogenazę glukozo 6-fosforanu produkującą NADPH [72]. W ryżu, oksydazę NADPH aktywuje również małe białko G RAC1 w formie RAC1-GTP. W wymianie GDP na GTP bierze udział białko GEF, fosforylowane przez kompleks wiążący chitynę [75]. Ponadto produkcja nadtlenku wodoru w apoplaście może się odbywać także niezależnie od oksydazy RBOH. W tym wypadku źródłem $\mathrm{H}_{2} \mathrm{O}_{2}$ są reakcje katalizowane przez peroksydazy klasy III (PRX33 i PRX34) [79,80].

Aktywne formy tlenu, produkowane $w$ apoplaście już po około 2-3 min od aplikacji MAMP/PAMP, mają właściwości toksyczne, ograniczające namnażanie fitopatogenów. Jednakże nadtlenek wodoru, będący najbardziej stabilną formą ROS, pełni również funkcję przekaźnika II rzędu. Sugeruje się, że zmiany poziomu $\mathrm{H}_{2} \mathrm{O}_{2} \mathrm{w}$ apoplaście moga być rejestrowane przez receptorowe kinazy białkowe bogate $\mathrm{w}$ domenie zewnątrzkomórkowej w cysteinę CRK (ang. Cysteine-Rich Protein Kinase) reagujące na zmiany oksydacyjno-redukcyjne. Taką rolę przypisuje się kinazie GHR1 i co najmniej niektórym z 44 kinaz CRK (CRK4, 6, 28 i 36) oddziałującym z AtFLS2 [79,80]. Warto także odnotować wyniki badań, które pokazują, że nadtlenek wodoru może być transportowany do cytoplazmy przez niektóre akwaporyny (AtPIP1;4), gdzie przypuszczalnie pełni szereg funkcji, m. in. związanych z aktywacją kanałów wapniowych lub kinaz CPK $[79,80]$. W ostatnim czasie spore zainteresowanie budzi także funkcja związana z odwracalną i nieodwracalną modyfikacją białek poprzez utlenianie reszt hydrosulfidowych w resztach cysteiny, które są przekształcane w grupy sulfenowe $\mathrm{SO}^{-}$, sulfinowe $\mathrm{SO}_{2}^{-}$, a dalej w reszty sulfonowe $\mathrm{SO}_{3}^{-}[80]$.

Kolejną cząsteczką sygnałową, której synteza jest aktywowana przez szlaki sygnałowe poniżej $\mathrm{H}_{2} \mathrm{O}_{2}$ jest tlenek azotu (NO). Co prawda, nadal nie ma pewności, która z kilku możliwych reakcji produkujących NO w roślinach staje się jego źródłem w reakcjach odpornościowych [81]. Niektóre wyniki sugerują, że w rzodkiewniku taką rolę odgrywa NOA1/2 (ang. NO-associated1/2), ale wyników rozstrzygających nadal brakuje. Rola $\mathrm{NO}$ w roślinach wiązana jest $\mathrm{z}$ regulacją wielu procesów, ale w reakcjach odpornościowych szczególnie interesujące są reakcje nitrozylacji reszt hydrosulfidowych, np. w RBOH czy w białku NPR1, które jest kluczowym elementem szlaków sygnałowych aktywowanych przez kwas salicylowy [81,82].

\section{AKTYWACJA KASKAD KINAZ MAP}

W wielu doświadczeniach, których celem była analiza zmian towarzyszących aktywacji receptorów PRR wykazano, że jedną z szybkich odpowiedzi obserwowanych już po 1-2 min jest aktywacja kaskad kinaz MAP [3,6,7,69,72,74]. Genomy rzodkiewnika i ryżu zawierają około 90-110 genów kodujaccych kinazy białkowe funkcjonujące w układach ka- skadowych MAPKKK>MAPKK>MAPK. Już w pierwszych doświadczeniach badających szlaki sygnałowe aktywowane przez flagelinę wykazano, że aplikacja flg22 aktywuje kinazy MPK3 i MPK6. W aktywacji obu kinaz biorą udział kinazy MKK4/MKK5, te zaś są aktywowane przez niezidentyfikowaną jeszcze kinazę MAPKKK [6,7,69,72,83,84] (Ryc. 7). Przez wiele lat nie było do końca jasne jak dochodzi do przekazywania sygnału z receptorów PRR na kaskady kinaz MAP. W doświadczeniach prowadzonych na mutantach bik1, pbl1, bsk1 nie potwierdzono sugestii, jakoby to kinazy białkowe RLCK odgrywały rolę pośrednika pomiędzy kompleksem AtFLS2/AtBAK1 a MAPKKK. Jednakże w ostatnim czasie wykazano doświadczalnie, że w rzodkiewniku kinaza PBL27 fosforylowana przez kompleks receptorowy CERK1/LYK5 wiążący chitynę aktywuję kaskadę MAPKKK5>MKK4/5>MPK3/6, zaś w ryżu podobną rolę odgrywa kinaza OsRLCK185 pośrednicząca pomiędzy kompleksem CEBIP/CERK1 a kaskadą obejmującą MAPKKK18> MKK4>MPK3/6 [85].

Mimo że nadal nie wiadomo jak następuje przekazywanie sygnału z kompleksu AtFLS2/flg22/AtBAK1 na nieznaną jeszcze kinazę MAPKKK, to jednak udział kinaz MPK3/ MPK6 w szlakach sygnałowych aktywowanych przez ten kompleks, jak również przez inne receptory typu PRR został już potwierdzony w wielu badaniach. W analizach przeprowadzonych w ostatnich latach wytypowano 538 białek substratowych, których fosforylacja przez MPK3/MPK6 prowadzi do przeprogramowania wielu procesów komórkowych [84]. Najliczniejszą grupę białek substratowych stanowią białka związane $\mathrm{z}$ regulacją ekspresji genów, w tym także liczne czynniki transkrypcyjne (patrz następny rozdział). Wśród innych białek fosforylowanych przez MPK3/ MPK6 warto wymienić enzymy ACS2/6 funkcjonujące w biosyntezie etylenu, białko TZF9 z palcem cynkowym wiążące RNA, białko LIP5 biorące udział w formowaniu ciał wielopeccherzykowych MVB, czy białka PHOS32/34 o nieznanej jeszcze funkcji (Ryc. 7) [7,74]. Bardziej złożona i słabo jeszcze poznana jest rola kaskady aktywującej kinazę MPK4 (MEKK1>MKK1/2>MPK4), która była identyfikowana jako element negatywny, hamujący odpowiedzi obronne. Jednakże z czasem okazało się, że kinaza MPK4 pełni również funkcję elementu pozytywnego $[6,7,69,74,83]$. Oprócz kinaz MPK3/6 i MPK4, których funkcjonowanie jest ewidentnie powiązane z odpornością typu PTI, wyniki pojedynczych prac dowodzą, że również MPK11, MPK1 czy MPK13 w różnym stopniu biorą udział w regulacji PTI [84]. Na przykład wykazano, że kinaza MPK11 fosforyluje GRF-6, jedno z białek 14-3-3, kierując go ubikwitynylacji i degradacji proteolitycznej, co sprzyja wzrostowi odporności przeciw wirusowi ospowatości śliwy [7].

\section{ODPOWIEDZI OBRONNE AKTYWOWANE PRZEZ RECEPTORY PRR}

\section{ZMIANY W EKSPRESJI GENÓW}

Większość odpowiedzi obronnych typu PTI wymaga szybkiego i selektywnego przeprogramowania ekspresji tysięcy genów. Analizy porównawcze zmian wywoływanych przez różne cząsteczki MAMP/PAMP/DAMP prowadzą do wniosku, że zakres zmian w ekspresji genów jest w zasadzie podobny, a różnice dotyczą głównie ich dynamiki i 
amplitudy. Trudniejsze w interpretacji są wyniki doświadczeń, w których roślina jest infekowana patogenem, ponieważ zmiany w ekspresji genów towarzyszące percepcji cząsteczek MAMP/PAMP/DAMP oraz zmiany wynikające z aktywacji wewnątrzkomórkowych receptorów typu NB-LRR nie są rozdzielone w czasie. Jednakże doświadczenia prowadzone na mutantach bakteryjnych z defektami w genach kodujących białka budujące III układ sekrecyjny, za pośrednictwem którego do komórek rośliny są wprowadzane białka efektorowe, dają pewne możliwości oddzielenia zmian związanych z PTI od zmian towarzyszących ETI [86].

Większość zmian w ekspresji genów związanych z PTI pozostaje pod kontrolą kinaz MAP, białek wiążących $\mathrm{Ca}^{2+} \mathrm{i}$ kinaz białkowych zależnych od jonów wapnia (CPK i CBL/ CIPK) (Ryc. 7). Kinazy MAP funkcjonują w regulacji ekspresji już na poziomie aktywacji polimerazy II (RNAPII) oraz wielobiałkowego kompleksu Mediatora [86]. Percepcja flg22, elf18 czy chityny aktywuje kinazy MPK3/MPK6, które fosforylują kinazę zależną od cyklin CDKC, która następnie fosforyluje podjednostkę Rpb1 kompleksu RNAPII. W regulacji ekspresji genów związanych z odpornością pośredniczy także, co najmniej kilka białek kompleksu Mediatora, chociaż na razie nie wiadomo, które z nich biorą udział w aktywacji PTI [86]. Selektywność transkrypcji zapewniają przede wszystkim czynniki transkrypcyjne kodowane $\mathrm{w}$ rzodkiewniku przez około 2000 genów pogrupowanych do ponad 70 rodzin. Jedną z większych rodzin, w rzodkiewniku liczącą 72, a w ryżu ponad 100 genów, jest rodzina WRKY. Geny $\mathrm{z}$ tej rodziny zajmują kluczowe miejsce w regulacji transkrypcji genów związanych z odpornością oraz stresem abiotycznym. Przeprowadzone w ostatnim czasie analizy wykazały, że kinazy MAP aktywowane przez AtFLS2 zmieniają dynamikę wiązania WRKY18, 40 i 33 do promotorów ponad 1000 genów [87]. Wyniki wcześniejszych badań pokazały, że czynnik transkrypcyjny WRKY33 fosforylowany prze MPK3/6 aktywuje ekspresję genów $R B O H$, genów ACS2/6 kodujących enzymy szlaku syntezy etylenu, genu PAD3 związanego z syntezą kamaleksyny, własnego genu WRKY33 oraz hamuje ekspresję genów związanych z syntezą ABA $[7,69,74,86]$. Kinaza MPK4 tworzy heterotrimer MPK4/MKS1/WRKY33, w którym fosforyluje białko MKS1 z motywem VQ, co w efekcie umożliwia wiązanie dimeru WRKY33/MKS1 z promotorem genu związanym z biosyntezą kamaleksyny [7,83]. Czynnik transkrypcyjny VIP1, należący do innej rodziny białek regulujących transkrypcję, fosforylowany przez kinazy MPK3/6 przemieszcza się z cytoplazmy do jądra, gdzie aktywuje ekspresję genów PR związanych z odpornością. Fosforylowanie przez MPK3/6 czynników transkrypcyjnych ERF6/104, należących do dużej rodziny białek AP2/ERF regulujących m. in. odpowiedzi na etylen, wpływa pozytywnie na ich stabilność i aktywację genów defensyn PDF1.2. (Ryc. 7) [7,74,86].

Wzrost stężenia jonów $\mathrm{Ca}^{+2} \mathrm{w}$ cytoplazmie i wiązanie ich do kalmoduliny prowadzi do aktywacji czynników transkrypcyjnych CBP60g i SARD1 aktywujących ekspresję genu ICS1 związanego z biosyntezą kwasu salicylowego oraz transkrypcję genów BAK1, BIK1, MPK3 [86]. Ekspresja wielu genów związanych z odpornością PTI jest regulowana również przez kinazy CPK (CPK4, 5, 6, 11) fosforylujące $\mathrm{m}$. in. niektóre czynniki transkrypcyjne WRKY. Na przykład, zwiększona ekspresja CPK5 i CPK11 aktywuje transkrypcję 100-200 genów, spośród których około $80 \%$ jest aktywowana przez flg22.

\section{ZAMYKANIE SZPAREK}

Już przed ponad dziesięciu laty zauważono, że w liściach traktowanych różnymi elicytorami wielkość szparek ulega wyraźnemu zmniejszeniu, oraz że cząsteczki MAMP/ PAMP hamują także aktywowane przez światło otwieranie szparek $[88,89]$. Wyjaśnienie tych zmian nie jest proste, gdyż nadal nie są do końca poznane mechanizmy regulujące ruchy aparatów szparkowych związanych ze zmianami oświetlenia, wilgotności powietrza, stężenia $\mathrm{CO}_{2}$, temperatury, czy z udziałem niektórych fitohormonów. Jednakże dzisiaj już wiadomo, że zmiany turgoru w wakuolach są powiązane ze zmianami kierunku ruchu jonów $\mathrm{K}^{+}$oraz $\mathrm{Cl}^{-}$, $\mathrm{NO}_{3}^{-}$i jabłczanowych pomiędzy apoplastem a cytoplazmą, a następnie pomiędzy cytoplazmą a wakuolą. Odpowiednio duża wartość potencjału błony plazmatycznej (-70 - -120 $\mathrm{mV}$ ) sprzyja otwieraniu kanałów potasowych, co umożliwia ruch $\mathrm{K}^{+} \mathrm{z}$ apoplastu do cytoplazmy. W tym samym kierunku transportowane są, przypuszczalnie na zasadzie kotransportu $\mathrm{z} \mathrm{H}^{+}$, aniony $\mathrm{Cl}^{-} \mathrm{i} \mathrm{NO}_{3}^{-}$. Transportowi $\mathrm{K}^{+} \mathrm{i}$ anionów z cytoplazmy do wakuoli towarzyszy napływ wody, prowadzący do wzrostu turgoru i otwierania aparatów szparkowych. Zamykanie szparek zachodzi w warunkach zmniejszonego pompowania protonów przez $\mathrm{H}^{+}$-ATPazę do apoplastu i obniżenia wartości potencjału błonowego oraz otwierania kanałów anionowych. Kluczową rolę w zamykaniu aparatów szparkowych odgrywają kanały anionowe SLAC1 i SLAH3, które są otwierane w następstwie ich fosforylacji. SLAC1 jest fosforylowany przez kinazę białkową OST1 (ang. Open Stomata1), a SLAH3 przez zależne od jonów wapnia kinazy CPK i CBL/CIPK. Wypływ anionów z komórek szparkowych prowadzi do dalszej depolaryzacji błony, co sprzyja otwieraniu kanałów $\mathrm{K}^{+}$. Ruch jonów $\mathrm{K}^{+}$do apoplastu wymusza wypływ wody z komórki, w wyniku czego następuje zmniejszenie turgoru prowadzącego do zamknięcia szparki [90].

Zamykanie aparatów szparkowych powiązane z aplikacją cząsteczki MAMP/PAMP/DAMP ma ścisły związek z produkcją nadtlenku wodoru i tlenku azotu oraz napływem $\mathrm{Ca}^{2+}$ do cytoplazmy $[79,80]$. Również w szlaku sygnałowym aktywowanym przez receptory PRR miejsce kluczowe zajmuje kinaza OST1 aktywująca kanały anionowe SLAC1, chociaż sugeruje się, że SLAC1 mogą być także aktywowane w szlaku zależnym od kinaz MAP [88], zaś kanały SLAH3 mogą fosforylować niektóre kinazy CPK i CBL/CIPK [90]. W zamykaniu aparatów szparkowych biorą również udział błonowe receptorowe kinazy białkowe GHR1 i CRK, które przypuszczalnie funkcjonują jako sensory zmian stanu oksydacyjno-redukcyjnego w apoplaście, a także oddziałująca z AtFLS2 kinaza LecRC VI. 2, której ligand nie został jeszcze poznany $[79,90]$.

\section{SYNTEZA I ODKŁADANIE KALOZY}

Kolejną odpowiedzią obronną, której występowanie jest równie często analizowane $\mathrm{w}$ badaniach odporności typu PTI, jest synteza i odkładanie $\mathrm{w}$ miejscu ataku patogena lub 
zranienia tkanki kalozy, wielkocząsteczkowego polisacharydu zbudowanego z glukozy połączonej wiązaniami $\beta$-1,3glikozydowymi. Zlokalizowany w błonie komórkowej kompleks syntazy kalozy (CalS) budują: enzym GSL (ang. Glucan Synthase-Like), w rzodkiewniku kodowany przez 12 genów, a także UDP-glukozo transferaza (UGT1), białko Rop1, syntaza sacharozy i aneksyna [91]. Synteza kalozy zachodzi razem z syntezą celulozy, co w efekcie prowadzi do powstawania sieci zbudowanej z obu polimerów [92]. Regulacja syntezy i odkładania kalozy odbywa się przypuszczalnie na poziomie transkrypcji genów GLS, regulacji transportu pęcherzykowego i regulacji formowania w błonie plazmatycznej kompleksów CalS, a przypuszczalnie także na drodze fosforylacji białek współtworzących kompleksy [91]. Po aplikacji cząsteczki MAMP/PAMP synteza i odkładanie kalozy w epidermie zachodzi dwufazowo, jako odpowiedź stosunkowo szybka (60-90 min po aplikacji) i odpowiedź przesunięta w czasie (znaczny wzrost dopiero po 5-6 godz. od aplikacji), która jest przypuszczalnie powiązana z aktywacją ekspresji genów GSL5, 611 oraz transportem pęcherzykowym enzymów i białek współtworzących kompleksy CalS [91,92]. Inaczej jest w przypadku, gdy tkanka jest infekowana przez grzyby patogenne, np. mączniaka prawdziwego. $W$ tym wypadku, w miejscu rosnącej na powierzchni strzępki, w błonie plazmatycznej tworzą się struktury „brodawkowate” wypełnione kalozą [92]. Ponadto doświadczalnie dowiedziono, że cząsteczki takie jak flg22 czy chityna aktywują syntezę i odkładanie kalozy w błonach plazmodesm. W tym wypadku dochodzi do ograniczenia lub nawet całkowitego zablokowania przepływu w symplaście różnych cząsteczek, w tym również wirusów.

\section{AKTYWACJA TRANSPORTU HEKSOZ \\ Z APOPLASTU DO CYTOPLAZMY}

Wiele organizmów patogennych wykształciło w toku ewolucji szereg specjalnych przystosowań, które są nakierowane na zwiększenie transportu cukrów i innych substancji pokarmowych z komórki, co ma poprawić ich dostępność w apoplaście. Taki rozdział cukrów pomiędzy symplastem a apoplastem sprzyja namnażaniu się fitopatogenów, szczególnie odżywiających się w apoplaście biotrofów [93]. Przykładem takiego przystosowania jest synteza w Xanthomonas oryzae białek efektorowych z rodziny TAL, które wprowadzone do komórek ryżu aktywują transkrypcję genów z rodziny SWEET liczącej około 20 genów. Wykazano doświadczalnie, że co najmniej kilka genów z tej rodziny koduje białka transportujące do apoplastu sacharozę. Ponadto wykazano, że infekcja bakteriami i grzybami patogennymi aktywuje w roślinie ekspresję genu kodującego zlokalizowaną w ścianie komórkowej inwertazę. Aktywność tej hydrolazy rozszczepiającej sacharozę na dwie heksozy hamowana jest przez białka inhibitorowe AtCIF1 i AtCIF2. Wykazano doświadczalnie, że gronowiec (grzyb powodujący szarą pleśń) hamuje ekspresję genów AtCIF1, AtCIF2, co w efekcie prowadzi do wzrostu w apoplaście poziomu heksoz [93]. W kontekście wyników tych badań można było zakładać, że również rośliny w toku ewolucji wykształciły pewne przystosowania, które będą przeciwdziałać niekorzystnemu dla rośliny podziałowi substancji pokarmowych. Przewidywania te okazały się trafne, bowiem $\mathrm{w}$ najnowszych badaniach wykazano, że cząsteczki MAMP/PAMP mogą aktywować reakcje obronne nakierowane na obniżanie poziomu monocukrów w apoplaście. Okazało się, że aplikacja flg22 na liście rzodkiewnika aktywuje ekspresję genu STP13 kodującego białko transportujące heksozy z apoplastu do cytoplazmy. Ponadto wykazano, że wiązanie flg22 przez AtFLS2/ AtBAK1 prowadzi do fosforylacji przez kinazę AtBAK1 białka AtSTP13. Fosforylacja zachowawczej reszty treoniny, położonej w części C-końcowej transportera, sprzyja wzrostowi transportu heksoz do cytoplazmy[94].

\section{AKTYWACJA FITOANCYPIN I BIOSYNTEZA FITOALEKSYN}

Synteza wtórnych metabolitów ograniczających namnażanie fitopatogenów może się odbywać konstytutywnie, tak jak to jest w przypadku fitoancypin, bądź może być aktywowana przez patogeny, tak jak to się dzieje w przypadku fitoaleksyn. Syntetyzowane fitoancypiny (saponiny, glikozydy cyjanogenne, glukozynolaty) są magazynowane w odpowiednich przedziałach komórkowych bądź w specjalnych komórkach (komórkach S). W oddzielnych przedziałach występują enzymy hydrolityczne funkcjonujące w szlakach metabolicznych, w których np. w przypadku glukozynolatów uwalniane są silnie toksyczne związki, modyfikujące reszty hydrosulfidowe i aminowe białek. Wyniki nielicznych jeszcze doświadczeń pokazują, że enzymy biorące udział w przemianach niektórych fitoancypin są aktywowane przez cząsteczki MAMP/PAMP [95].

Fitoaleksyny są związkami lipofilowymi z grupy stilbenów, flawonoidów oraz terpenoidów syntetyzowanymi przez rośliny w odpowiedzi na atak fitopatogenów. Liczba zidentyfikowanych $\mathrm{w}$ różnych roślinach fitoaleksyn sięga już ponad 200 związków. Wiele z nich to substancje pochodne tryptofanu zawierające siarkę (kamaleksyna), związki pochodne fenyloalaniny (gliceolina), czy pochodne diterpenów (oryzaleksyna A) [95,96]. Jedną z najlepiej poznanych fitoaleksyn jest kamaleksyna, syntetyzowana $\mathrm{w}$ roślinach $\mathrm{z}$ rodziny kapustowatych. W rzodkiewniku udało się poznać szereg enzymów funkcjonujących w szlaku biosyntezy kamaleksyny. Poznano także niektóre elementy szlaków sygnałowych aktywowanych przez MAMP/PAMP regulujących jej biosyntezę (Ryc. 7). Jak już wcześniej wspomniano, w regulacji ekspresji genów kodujących enzymy szlaku biosyntezy kamaleksyny biorą udział czynniki transkrypcyjne WRKY33, 18 i 40, a elementami szlaków sygnałowych są: kinazy MPK3/6 i MPK4, nadtlenek wodoru i kwas salicylowy $[7,96]$.

\section{PRODUKCJA BIAŁEK ZWIĄZANYCH Z ODPORNOŚCIĄ (PR) ORAZ PEPTYDÓW ANTYBAKTERYJNYCH}

$W$ wielu doświadczeniach, których wyniki były przytaczane $\mathrm{w}$ poprzednich rozdziałach, analizowaną odpowiedzią na aplikowane cząsteczki MAMP/PAMP była aktywacja ekspresji genów PR (ang. Pathogenesis-Related) [97]. Wiele białek PR występuje w roślinach w niewielkich stężeniach, jednakże poziom niektórych $\mathrm{z}$ nich gwałtownie rośnie po aplikacji cząsteczki MAMP/PAMP, zainfekowaniu rośliny fitopatogenem bądź zadziałaniu abiotycznych czynników stresogennych [97]. Na podstawie homologii sekwencji aminokwasowej białka PR zostały podzielone na 17 rodzin. Białka z kilku rodzin wykazują aktywność enzymatyczną, 
w tym m. in. $\beta$-1,3-glukanazową, chitynazową, proteazową (subtylizyno-podobną), peroksydazową czy rybonukleazową, a białka $\mathrm{z}$ rodziny 6 działają jako inhibitory różnych proteaz. Ponadto białka $\mathrm{z}$ kilku innych rodzin są probiałkami, z których są wycinane małe, 20-50-aminokwasowe peptydy antybakteryjne (defensyny, tioniny, heweiny, snakiny, knotyny, peptydy LTP). Jednakże oprócz peptydów antybakteryjnych wycinanych z białek PR, szereg peptydów o podobnym działaniu pochodzi z innych probiałek (cyklotydy) bądź jest kodowany przez małe ORF [98].

Mechanizm działania białek PR z aktywnością enzymatyczną wydaje się być możliwy do przewidzenia, ale funkcjonowanie pozostałych białek pozostaje ciacgle zagadkowe. Przykładem są białka z rodziny PR-1, których ekspresja jest bardzo często analizowana w doświadczeniach badających odpowiedzi na infekcję lub aplikację cząsteczek MAMP/ PAMP/DAMP. Wyniki najnowszych badań dowodzą, że białka z rodziny PR-1 mają motyw CAP wiążący sterole, ale mogą być także probiałkami, z których są wycinane 11-aminokwasowe peptydy CAPE, a w niektórych roślinach poznano receptorowe kinazy białkowe, które w części zewnątrzkomórkowej mają motyw CAP [99]. Podobnie niewiele wiemy o mechanizmach działania peptydów antybakteryjnych. Obecnie przyjmuje się, że niektóre peptydy zwiększają przepuszczalność błon, zaś inne oddziałują z enzymami i różnymi innymi białkami oraz z kwasami nukleinowymi [98].

\section{SYNTEZA FITOHORMONÓW ZWIAZZANYCH Z ODPORNOŚCIĄ I USTALANIE KOMPROMISU POMIĘDZY ODPORNOŚCIĄ A WZROSTEM ROŚLINY}

Jak już wcześniej wspomniano, aktywacja kinaz MPK3/6 i wzrost stężenia $\mathrm{Ca}^{2+} \mathrm{w}$ cytoplazmie prowadzi do zmian w ekspresji wielu genów, w tym także genów związanych z biosyntezą etylenu (ET) i kwasu salicylowego (SA). Aplikacja flg22 na liście rzodkiewnika już po 1 godz. aktywuje syntezę ET, a po 3-6 godz. syntezę SA, lecz nie wpływa na biosyntezę kwasu jasmonowego (JA), trzeciego ważnego fitohormonu związanego z odpornością typu PTI. Syntezę tego fitohormonu aktywuje w ziemniaku peptyd Pep-13, cząsteczka typu PAMP pochodząca z lęgniowców z rodzaju Phytophthora $[7,74]$. Przyjmuje się powszechnie, że SA odgrywa rolę kluczową w odporności przeciw bio- i hemibiotrofom, natomiast ET i JA funkcjonują głównie w odporności przeciw nekrotrofom. Mimo to, w doświadczeniach prowadzonych na odpowiednich, wielokrotnych mutantach rzodkiewnika (dde2/ein2/pad4/sid2) wykazano, że wszystkie trzy fitohormony wpływają pozytywnie na wystąpienie odpowiedzi na aplikację flg22, oraz że szlaki sygnałowe aktywowane przez te fitohormony działają synergicznie. Ponadto ujawniono, że po aplikacji MAMP/PAMP pierwsze zmiany w ekspresji genów występują już w ciągu 15 min, i to niezależnie od SA, ET i JA, ale już po 1 godz. pojawiają się zmiany powiązane z syntezą i aktywnością tych fitohormonów [7]. Co więcej, wykazano, że aż 80\% odpowiedzi aktywowanych przez cząsteczki MAMP/PAMP nie występuje $\mathrm{u}$ mutantów wielokrotnych $\mathrm{z}$ defektami w biosyntezie lub w szlakach sygnałowych aktywowanych przez te fitohormony [86].
Na zakończenie warto jeszcze zwrócić uwagę na rolę SA, ET i JA, ale także pozostałych, klasycznych fitohormonów oraz poznawanych obecnie hormonów peptydowych $\mathrm{w}$ równoważeniu procesów związanych ze wzrostem i odpornością rośliny. Koncepcja zakładająca funkcjonowanie w roślinach mechanizmu molekularnego umożliwiającego ustalanie kompromisu pomiędzy wzrostem a odpornością (ang. growth-defense tradeoffs) powstała na podstawie obserwacji wskazujących, że aplikacja cząsteczek MAMP/PAMP prowadzi do zahamowania wzrostu rośliny [3]. Konkurowanie przeciwstawnych procesów o określoną pulę energetyczną rośliny pociąga konieczność ustalania pewnych kompromisów, które pozwolą roślinie zakwitnać i wydać nasiona. Dzisiaj już wiadomo, że szlaki sygnałowe aktywowane przez cząsteczki MAMP/PAMP/DAMP funkcjonują w skomplikowanej sieci sygnałowej, którą współtworzą również szlaki aktywowane przez wszystkie znane fitohormony [100]. Występowanie w tych szlakach wielu wspólnych elementów daje możliwość wzajemnego komunikowania pomiędzy szlakami aktywującymi reakcje odpornościowe, oraz szlakami regulującymi wzrost i rozwój rośliny. Takimi przykładowymi elementami pozwalającymi na wzajemne krzyżowanie się szlaków aktywowanych przez cząsteczki MAMP/PAMP i szlaków regulujących wzrost i rozwój aktywowanych przez brasinosteroidy (Br) są: kinaza BAK1, kinazy BSK1 i BIK1, czynniki transkrypcyjne BZR1 i HB1. Okazało się, że kinaza BIK1 fosforylowana przez kompleks AtFLS2/AtBAK1 fosforyluje receptor BR (BRI1) powodując supresję szlaku aktywowanego przez BR. Czynniki transkrypcyjne BZR1 i HBI1 są elementami pozytywnymi w szlaku aktywowanym przez BR, ale hamują odpowiedzi obronne typu PTI $[6,100]$. Innym przykładem oddziaływań pomiędzy hormonami związanymi z odpornością, a hormonami wzrostowymi jest hamowanie syntezy IAA przez SA. Wzrost syntezy kwasu salicylowego, wiązanego m. in. do katalazy (CAT2) i hamującego jej aktywność katalityczną, prowadzi do lokalnego wzrostu stężenia $\mathrm{H}_{2} \mathrm{O}_{2}$ powodującego sulfenylację podjednostki syntetazy tryptofanowej (TSB1). Zahamowanie syntezy tryptofanu prowadzi do obniżenia poziomu IAA [72]. Podobnych przykładów przeciwstawnego działania cząsteczek MAMP/PAMP/DAMP z wieloma hormonami, ale także szeregu hormonów z innymi fitohormonami poznano już wiele [100], tym niemniej nadal jednym z największych wyzwań biologii molekularnej roślin pozostaje całkowite rozszyfrowanie skomplikowanych sieci sygnałowych regulujących reakcje obronne i procesy wzrostu i rozwoju roślin.

\section{PIŚMIENNICTWO}

1. Jones JDG, Dangl JL (2006) The plant immune system. Nature 444: 323329

2. Chisholm ST, Coaker G, Day B, Staskawicz BJ (2006) Host-microbe interactions: shaping the evolution of the plant immune response. Cell 124: 803-814

3. Boller T, Felix G (2009) A renaissance of elicitors: perception of microbe-associated molecular patterns and danger signals by pattern-recognition receptors. Annu Rev Plant Biol 60: 379-406

4. Schwessinger B, Ronald PC (2012) Plant innate immunity: perception of conserved microbial signatures. Annu Rev Plant Biol 63: 451-482

5. Ranf S (2017) Sensing of molecular patterns through cell surface immune receptors. Curr Opin Plant Biol 38: 68-77 
6. Tang D, Wang G, Zhou J-M (2017) Receptor kinases in plant-pathogen interactions: more than pattern recognition. Plant Cell 29: 618-637

7. Bigeard J, Colcombet J, Hirt H (2015) Signaling mechanisms in pattern-triggered immunity (PTI). Mol Plant 8: 521-539

8. Macho AP, Zipfel C (2015) Targeting of plant pattern recognition receptor-triggered immunity by bacterial type-III secretion system effectors. Curr Opin Microbiol 23: 14-22

9. Macho AP (2015) Subversion of plant cellular functions by bacterial type-III effectors: beyond suppression of immunity. New Phytol 210: 51-57

10. Cui H, Tsuda K, Parker JE (2015) Effector-triggered immunity: from pathogen perception to robust defense. Annu Rev Plant Biol 66: 487511

11. Gao Q-M, Zhu S, Kachroo P, Kachroo A (2015) Signal regulators of systemic acquired resistance. Front Plant Sci 6: 1-12

12. Conrath U (2009) Priming of induced plant defense responses. Adv Bot Res 51: 361-395

13. Zhu Q-H, Shan W-X, Ayliffe MA, Wang M-B (2016) Epigenetic mechanisms: An emerging player in plant-microbe interactions. Mol Plant-Microbe Interact 29: 187-196

14. Martinez-Medina A, Flors V, Heil M, Mauch-Mani B, Pieterse CMJ, Pozo MJ, Ton J, van Dam NM, Conrath U (2016) Recognizing plant defense priming. Trends Plant Sci 21: 818-822

15. Balmer A, Pastor V, Gamir J, Flors V, Mauch-Mani B (2015) The "prime-ome": towards a holistic approach to priming. Trends Plant Sci 20: $443-452$

16. Boller T (1995) Chemoperception of microbial signals in plant cells. Annu Rev Plant Physiol Plant Mol Biol 46: 189-214

17. Gómez-Gómez L, Boller T (2000) FLS2: An LRR receptor-like kinase involved in the perception of the bacterial elicitor flagellin in Arabidopsis. Mol Cell 5: 1003-1011

18. Ronald PC, Beutler B (2010) Plant and animal sensors of conserved microbial signatures. Science 330: 1061-1064

19. Lehti-Shiu MD, Zou C, Hanada K, Shiu S-H (2009) Evolutionary history and stress regulation of plant receptor-like kinase/Pelle genes. Plant Physiol 150: 12-26

20. Li L, Yu Y, Zhou Z, Zhou J-M (2016) Plant pattern-recognition receptors controlling innate immunity. Sci China Life Sci 59: 878-888

21. Dardick C, Schwessinger B, Ronald P (2012) Non-arginine-aspartate (non-RD) kinases are associated with innate immune receptors that recognize conserved microbial signatures. Curr Opin Plant Biol 15: 358-366

22. Ma X, Xu G, He P, Shan L (2016) SERKing coreceptors for receptors. Trends Plant Sci 21: 1017-1033

23. Gust AA, Felix G (2014) Receptor like proteins associate with SORIR1-type of adaptors to form bimolecular receptor kinases. Curr Opin Plant Biol 21: 104-111

24. Zipfel C (2014) Plant pattern-recognition receptors. Trends Immunol 7:345-351

25. Böhm H, Albert I, Fan L, Reinhard A, Nürnberger T (2014) Immune receptor complexes at the plant cell surface. Curr Opin Plant Biol 20: 47-54

26. Han Z, Sun Y, Chai J (2014) Structural insight into the activation of plant receptor kinases. Curr Opin Plant Biol 20: 55-63

27. Sun Y, Li L, Macho AP, Han Z, Hu Z, Zipfel C, Zhou J-M, Chai J (2013) Structural basis for flg22-induced activation of the Arabidopsis FLS2-BAK1 immune complex. Science 342: 624-628

28. Beck M, Wyrsch I, Strutt J, Wimalasekera R, Webb A, Boller T, Robatzek S (2014) Expression patterns of FLAGELLIN SENSING2 map to bacterial entry sites in plant shoots and roots. J Exp Bot 65: 6487-6498

29. Hind SR, Strickler SR, Boyle PC, Dunham DM, Bao Z, O'Doherty IM, Baccile JA, Hoki JS, Viox EG, Clarke CR, Vinatzer BA, Schroeder FC, Martin GB (2016) Tomato receptor FLAGELLIN-SENSING 3 binds flgII-28 and activates the plant immune system. Nature Plants 2: 16128

30. Katsuragi Y, Takai R, Furukawa T, Hirai H, Morimoto T, Katayama T, Murakami T, Che F-S (2015) CD2-1, the C-terminal region of flagellin, modulates the induction of immune responses in rice. Mol Plant-Microbe Interact 28: 648-658

31. Erbs G, Newman M-A (2012) The role of lipopolysaccharide and peptidoglycan, two glycosylated bacterial microbe-associated molecular patterns (MAMPs), in plant innate immunity. Mol Plant Pathol 13: 95104

32. Gust AA, Willmann R, Desaki Y, Grabherr HM, Nürnberger T (2012) Plant LysM proteins: modules mediating symbiosis and immunity. Trends Plant Sci 17: 495-502

33. Gust AA (2015) Peptidoglycan perception in plants. PLOS Pathog 11: e1005275

34. Mgcina LS, Dubery IA, Piater LA (2015) Comparative conventionaland quantum dot-labeling strategies for LPS binding site detection in Arabidopsis thaliana mesophyll protoplasts. Front Plant Sci 6: 1-11

35. Ranf S, Gisch N, Schäffer M, Illig T, Westphal L, Knirel YA, Sánchez-Carballo PM, Zhringer U, Hückelhoven R, Lee J, Sheel D (2015) A lectin S-domain receptor kinase mediates lipopolysaccharide sensing in Arabidopsis thaliana. Nature Immunol 16: 426-433

36. Ranf S (2016) Immune sensing of lipopolysaccharide in plants and animals: same but different. PLOS Pathog 12: e1005596

37. Mott GA, Thakur S, Smakowska E, Wang PW, Belkhadir Y, Desveaux D, Guttman DS (2016) Genomic screens identify a new phytobacterial microbe-associated molecular pattern and the cognate Arabidopsis receptor-like kinase that mediates its immune elicitation. Genome Biol 17: 98

38. Kunze G, Zipfel C, Robatzek S, Niehaus K, Boller T, Felix G (2004) The $\mathrm{N}$ terminus of bacterial elongation factor Tu elicits innate immunity in Arabidopsis plants. Plant Cell 16: 3496-3507

39. Furukawa T, Inagaki H, Takai R, Hirai H, Che F-S (2014) Two distinct EF-Tu epitopes induce immune responses in rice and Arabidopsis. Mol Plant-Microbe Interact 27: 113-124

40. Zhang H, Wang S (2013) Rice versus Xanthomonas oryzae pv. oryzae: a unique pathosystem. Curr Opin Plant Biol 16: 188-195

41. Pruitt RN, Schwessinger B, Joe A, Thomas N, Liu F, Albert M, Robinson MR, Chan LJG, Luu DD, Chen H, Bahar O, Daudi A, De Vleesschauwer D, Caddell D, Zhang W, Zhao X, Li X, Heazlewood JL, Ruan D, Majumder D, Chern M, Kalbacher H, Midha S, Patil PB, Sonti RV, Petzold CJ, Liu CC, Brodbelt JS, Felix G, Ronald PC (2015) The rice immune receptor $X A 21$ recognizes a tyrosine-sulfated protein from a Gram-negative bacterium. Sci Adv 1: e1500245

42. Felix G, Boller T (2003) Molecular sensing of bacteria in plants. The highly conserved RNA-binding motif RNP-1 of bacterial cold shock proteins is recognized as an alicitor signal in tobacco. J Biol Chem 278: 6201-6208

43. Saur IML, Kadota Y, Sklenar J, Holton NJ, Smakowska E, Belkhadir Y, Zipfel C, Rathjen JP (2016) NbCSPR underlies age-dependent immune responses to bacterial cold shock protein in Nicotiana benthamiana. Proc Natl Acad Sci USA 113: 3389-3394

44. Wang L, Albert M, Einig E, Furst U, Krust D, Felix G (2016) The pattern-recognition receptor CORE of Solanaceae detects bacterial cold-shock protein. Nature Plants 2: 16185

45. Böhm H, Albert I, Oome S, Raaymakers TM, Van den Ackerveken G, Nürnberger T (2014) A conserved peptide pattern from a widespread microbial virulence factor triggers pattern-induced immunity in Arabidopsis. PLOS Pathog 10: e1004491

46. Albert I, Böhm H, Albert M, Feiler CE, Imkampe J, Wallmeroth N, Brancato C, Raaymakers TM, Oome S, Zhang H, Krol E, Grefen C, Gust AA, Chai J, Hedrich R, Van den Ackerveken G, Nürnberger T (2015) An RLP23-SOBIR1-BAK1 complex mediates NLP-triggered immunity. Nature Plants 1: 15140

47. Jehle AK, Lipschis M, Albert M, Fallahzadeh-Mamaghani V, Fürst U, Mueller K, Felix G (2013) The receptor-like protein ReMAX of Arabidopsis detects the microbe-associated molecular pattern eMax from Xanthomonas. Plant Cell 25: 2330-2340

48. Fawke S, Doumane M, Schornack S (2015) Oomycete interactions with plants: Infection strategies and resistance principles. Microbiol Mol Biol Rev 79: 263-279 
49. Kaku H, Shibuya N (2016) Molecular mechanisms of chitin recognition and immune signaling by LysM-receptors. Physiol Mol Plant Pathol 95: 60-65

50. Shinya T, Nakagawa T, Kaku H, Shibuya N (2015) Chitin-mediated plant-fungal interactions: catching, hiding and handshaking. Curr Opin Plant Biol 26: 64-71

51. Cao Y, Liang Y, Tanaka K, Nguyen CT, Jedrzejczak RP, Joachimiak A, Stacey G (2014) The kinase LYK5 is a major chitin receptor in Arabidopsis and forms a chitin-induced complex with related kinase CERK1. eLIFE 3: e03766

52. Ron M, Avni A (2004) The receptor for the fungal elicitor ethylene-inducing xylanase is a member of a resistance-like gene family in tomato. Plant Cell 16: 1604-1615

53. Bar M, Sharfman M, Ron M, Avni A (2010) BAK1 is required for the attenuation of ethylene-inducing xylanase (Eix)-induced defense responses by the decoy receptor LeEix1. Plant J 63: 791-800

54. Poinssot B, Vandelle E, Bentéjac M, Adrian M, Levis C, Brygoo Y, Garin J, Sicilia F, Coutos-Thévenot P, Pugin A (2003) The endopolygalacturonase 1 from Botrytis cinerea activates grapevine defense reactions unrelated to its enzymatic activity. Mol Plant-Microbe Interact 16: 553 564

55. Zhang L, Kars I, Essenstam B, Liebrand TWH, Wagemakers L, Elberse J, Tagkalaki P, Tjoitang D, Van den Ackerveken G, Van Kan JAL (2014) Fungal endopolygalacturonases are recognized as microbe-associated molecular patterns by the Arabidopsis receptor-like protein RESPONSIVENESS TO BOTRYTIS POLYGALACTURONASES1. Plant Physiol 164: 352-364

56. Kawchuk LM, Hachey J, Lynch DR, Kulcsar F, Van Rooijen G, Waterer DR, Robertson A, Kokko E, Byers R, Howard RJ, Fischer R, Prüfer D (2001) Tomato Ve disease resistance genes encode cell surface-like receptors. Proc Natl Acad Sci USA 98: 6511-6515

57. de Jonge R, Van Esse HP, Maruthachalam K, Bolton MD, Santhanam P, Saber MK, Zhang Z, Usami T, Lievens B, Subbarao KV (2012) Tomato immune receptor Ve1 recognizes effector of multiple fungal pathogens uncovered by genome and RNA sequencing. Proc Natl Acad Sci USA 109: 5110-5115

58. Zhang W, Fraiture M, Kolb D, Löffelhardt B, Desaki Y, Boutrop FFG, Tör M, Zipfel C, Gust AA, Brunner F (2013) Arabidopsis RECEPTOR-LIKE PROTEIN30 and receptor-like kinase SUPPRESSOR OF BIR11/EVERSHED mediate innate immunity to necrotrophic fungi. Plant Cell 25: 4227-4241

59. Derevnina L, Dagdas YF, De la Concepcion JC, Bialas A, Kellner R Petre B, Domazakis E, Du J, Wu C-H, Lin X, Aguilera-Galvez C, Cruz-Mireles N, Vleeshouwers VGAA, Kamoun S (2016) Nine things to know about elicitins. New Phytol 212: 888-895

60. Du J, Verzaux E, Chaparro-Garcia A, Bijsterbosch G, Keizer LCP Zhou J, Liebrand TWH, Xie C, Govers F, Robatzek S, van der Vossen EAG, Jacobsen E, Visser RGF, Kamoun S, Vleeshouwers VGAA (2015) Elicitin recognition confers enhanced resistance to Phytophthora infestans in potato. Nature Plants 1: 15034

61. Gust AA, Pruitt R, Nürnberger T (2017) Sensing danger: Key to activating plant immunity. Trends Plant Sci 22: 779-791

62. Ferrari S, Savatin DV, Sicilia F, Gramegna G, Cervone F, De Lorenzo G (2013) Oligogalacturonides: plant damage-associated molecular patterns and regulators of growth and development. Front Plant Sci 4: 49

63. Brutus A, Sicilia F, Macone A, Cervone F, De Lorenzo G (2010) A domain swap approach reveals a role of the plant wall-associated kinase 1 (WAK1) as a receptor of oligogalacturonides. Proc Natl Acad Sci USA 107: 9452-9457

64. Tanaka K, Choi J, Cao Y, Stacey G (2014) Extracellular ATP acts as a damage-associated molecular pattern (DAMP) signal in plants. Front Plant Sci 5: 446

65. Choi J, Tanaka K, Cao Y, Qi Y, Qiu J, Liang Y, Lee SY, Stacey G (2014) Identification of a plant receptor for extracellular ATP. Science 343: 290-294

66. Bartels S, Boller T (2015) Quo vadis, Pep? Plant elicitor peptides at the crossroads of immunity, stress, and development. J Exp Bot 66: 51835193
67. Tang J, Han Z, Sun Y, Zhang H, Gong X, Chai J (2015) Structural basis for recognition of an endogenous peptide by the plant receptor kinase PEPR1. Cell Res 25: 110- 120

68. Hou S, Wang X, Chen D, Yang X, Wang M, Turra D, Di Pietro A Zhang W (2014) The secreted peptide PIP1 amplifies immunity through receptor-like kinase 7. PLOS Pathog 10: e1004331

69. Couto D, Zipfel C (2016) Regulation of pattern recognition receptor signalling in plants. Nat Rev Immunol 16: 537-552

70. Burkart RC, Stahl Y (2017) Dynamic complexity: plant receptor complexes at the plasma membrane. Curr Opin Plant Biol 40: 15-21

71. Yasuda S, Okada K, Saijo Y (2017) A look at plant immunity through the window of the multitasking coreceptor BAK1. Curr Opin Plant Biol 38: 10-18

72. Withers J, Dong X (2017) Post-translational regulation of plant immunity. Curr Opin Plant Biol 38: 124-132

73. Macho AP, Zipfel C (2014) Plant PRRs and the activation of innate immune signaling. Mol Cell 54: 263-272

74. Tena G, Boudsocq M, Sheen J (2011) Protein kinase signaling networks in plant innate immunity. Curr Opin Plant Biol 14: 519-529

75. Yuan P, Jauregui E, Du L, Tanaka K, Poovaiah BW (2017) Calcium signatures and signaling events orchestrate plant-microbe interactions. Curr Opin Plant Biol 38: 173-183

76. Seybold H, Trempel F, Ranf S, Scheel D, Romeis T, Lee J (2014) $\mathrm{Ca}^{2+}$ signalling in plant immune response: from pattern recognition receptors to $\mathrm{Ca}^{2+}$ decoding mechanisms. New Phytol 204: 782-790

77. Ranf S, Eschen-Lippold L, Frhlich K, Westphal L, Scheel D, Lee J (2014) Microbe-associated molecular pattern-induced calcium signaling requires the receptor-like cytoplasmic kinases, PBL1 and BIK1. BMC Plant Biol 14: 374

78. Yoshioka H, Adachi H, Nakano T, Miyagawa N, Asai S, Ishihama N, Yoshioka M (2016) Hierarchical regulation of NADPH oxidase by protein kinases in plant immunity. Physiol Mol Plant Pathol 95: 20-26

79. Qi J, Wang J, Gong Z, Zhou J-M (2017) Apoplastic ROS signaling in plant immunity. Curr Opin Plant Biol 38: 92-100

80. Kimura S, Waszczak C, Hunter K, Wrzaczek M (2017) Bound by fate: The role of reactive oxygen species in receptor-like kinase signaling. Plant Cell 29: 638-654

81. Bellin D, Asai S, Delledonne M, Yoshioka H (2013) Nitric oxide as a mediator for defense responses. Mol Plant-Microbe Interact 26: 271277

82. Domingos P, Prado AM, Wong A, Gehring C (2015) Nitric oxide: A multitasked signaling gas in plants. Mol Plant 8: 506-520

83. Rasmussen MW, Roux M, Petersen M, Mundy J (2012) MAP kinase cascades in Arabidopsis innate immunity. Front Plant Sci 3: 169

84. Lee J, Eschen-Lippold L, Lassowskat I, Böttcher C, Scheel D (2015) Cellular reprogramming through mitogen-activated protein kinases. Front Plant Sci 6: 940

85. Yamada K, Yamaguchi K, Yoshimura S, Terauchi A, Kawasaki T (2017) Conservation of chitin-induced MAPK signaling pathways in rice and Arabidopsis. Plant Cell Physiol 58: 993-1002

86. Li B, Meng X, Shan L, He P (2016) Transcriptional regulation of pattern-triggered immunity in plants. Cell Host Microbe 19: 641-650

87. Birkenbihl RP, Kracher B, Roccaro M, Somssich IE (2017) Induced genome-wide binding of three Arabidopsis WRKY transcription factors during early MAMP-triggered immunity. Plant Cell 29: 20-38

88. Ye W, Murata Y (2016) Microbe associated molecular pattern signaling in guard cells. Front Plant Sci 7: 583

89. Arnaud D, Hwang I (2015) A sophisticated network of signaling pathways regulates stomatal defenses to bacterial pathogens. Mol Plant 8: 566-581

90. Hedrich R, Geiger D (2017) Biology of SLAC1-type anion channels from nutrient uptake to stomatal closure. New Phytol 216: 46-61

91. Ellinger D, Voigt CA (2014) Callose biosynthesis in arabidopsis with a focus on pathogen response: what we have learned within the last decade. Ann Bot 114: 1349-1358 
92. Schneider R, Hanak T, Persson S, Voigt CA (2016) Cellulose and callose synthesis and organization in focus, what's new? Curr Opin Plant Biol 34: 9-16

93. Naseem M, Kunz M, Dandekar T (2017) Plant-pathogen maneuvering over apoplastic sugars. Trends Plant Sci 22: 740-743

94. Yamada K, Saijo Y, Nakagami H, Takano Y (2016) Regulation of sugar transporter activity for antibacterial defense in Arabidopsis. Science 354: 1427-1430

95. Piasecka A, Jedrzejczak-Rey N, Bednarek P (2015) Secondary metabolites in plant innate immunity: conserved function of divergent chemicals. New Phytol 206: 948-964

96. Ahuja I, Kissen R, Bones AM (2012) Phytoalexins in defense against pathogens. Trends Plant Sci 17: 73-90
97. Sudisha J, Sharathchandra RG, Amruthesh KN, Kumar A, Shetty HS (2012) Pathogenesis Related Proteins in plant defense response. W: Mérillon JM, Ramawat KG (red) Plant Defence: Biological Control, Springer Science, str. 379-403

98. Goyal RK, Mattoo AK (2016) Plant antimicrobial peptides. W: Epand RM (red) Host Defense Peptides and Their Potential as Therapeutic Agents, Springer, str. 111-136

99. Breen S, Williams SJ, Outram M, Kobe B, Solomon PS (2017) Emerging insights into the functions of Pathogenesis-Related Protein 1. Trends Plant Sci 22: 871-879

100. Huot B, Yao J, Montgomery BL, He SY (2014) Growth-defense tradeoffs in plants: A balancing act to optimize fitness. Mol Plant 7: 12671287

\title{
Membrane receptors recognizing MAMP/PAMP and DAMP molecules that activate first line of defence in plant immune system
}

\section{Anna Hetmann $\bowtie$, Stanisław Kowalczyk}

Nicolaus Copernicus University, Faculty of Biology and Environmental Protection, Department of Biochemistry, 1 LwowskaSt., 87-100 Torun, Poland

®e-mail: ahetmann@umk.pl

Key words: plant basal resistance, receptors recognizing MAMP/PAMP and DAMP molecules, defence responses

\begin{abstract}
Plants have evolved a multilevel immune system to protect them against infection by a diverse range of pathogens. The first line of plant defense consists of the integral plasma membrane receptors, known as pattern-recognition receptors (PRRs), which recognize MAMP/PAMP or DAMP molecules. PRRs activate downstream signaling cascades that culminate in generation of the innate immune response, called PAMP-triggered immunity (PTI). The activation of PTI leads to the induction of basal defense responses, which include influx of $\mathrm{Ca}^{2+}$ in the cytosol, production of reactive oxygen species (ROS) and nitric oxide, activation of mitogen-activated protein kinase cascades, callose deposition, stomatal closure, phytoalexins biosynthesis, defence hormone biosynthesis and transcriptional induction of a large suite of defence-related genes.
\end{abstract}

